\title{
Simulation of Mexico City plumes during the MIRAGE-Mex field campaign using the WRF-Chem model
}

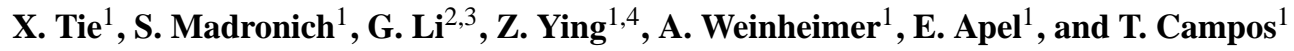 \\ ${ }^{1}$ National Center for Atmospheric Research, Boulder, CO USA \\ ${ }^{2}$ Molina Center for Energy and the Environment, La Jolla, CA \\ ${ }^{3}$ Department of Atmospheric Sciences, Texas A\&M, USA \\ ${ }^{4}$ Earth and Space Science, York University, Canada
}

Received: 19 March 2009 - Published in Atmos. Chem. Phys. Discuss.: 8 April 2009

Revised: 25 June 2009 - Accepted: 9 July 2009 - Published: 17 July 2009

\begin{abstract}
The quantification of tropospheric $\mathrm{O}_{3}$ production in the downwind of the Mexico City plume is a major objective of the MIRAGE-Mex field campaign. We used a regional chemistry-transport model (WRF-Chem) to predict the distribution of $\mathrm{O}_{3}$ and its precursors in Mexico City and the surrounding region during March 2006, and compared the model with in-situ aircraft measurements of $\mathrm{O}_{3}, \mathrm{CO}$, VOCs, $\mathrm{NO}_{\mathrm{x}}$, and $\mathrm{NO}_{\mathrm{y}}$ concentrations. The comparison shows that the model is capable of capturing the timing and location of the measured city plumes, and the calculated variability along the flights is generally consistent with the measured results, showing a rapid increase in $\mathrm{O}_{3}$ and its precursors when city plumes are detected. However, there are some notable differences between the calculated and measured values, suggesting that, during transport from the surface of the city to the outflow plume, ozone mixing ratios are underestimated by about $0-25 \%$ during different flights. The calculated $\mathrm{O}_{3}$ $\mathrm{NO}_{\mathrm{x}}, \mathrm{O}_{3}-\mathrm{CO}$, and $\mathrm{O}_{3}-\mathrm{NO}_{\mathrm{z}}$ correlations generally agree with the measured values, and the analyses of these correlations suggest that photochemical $\mathrm{O}_{3}$ production continues in the plume downwind of the city (aged plume), adding to the $\mathrm{O}_{3}$ already produced in the city and exported with the plume. The model is also used to quantify the contributions to $\mathrm{OH}$ reactivity from various compounds in the aged plume. This analysis suggests that oxygenated organics (OVOCs) have the highest $\mathrm{OH}$ reactivity and play important roles for the $\mathrm{O}_{3}$ production in the aging plume. Furthermore, $\mathrm{O}_{3}$ produc-
\end{abstract}

Correspondence to: $\mathrm{X}$. Tie (xxtie@ucar.edu ) tion per $\mathrm{NO}_{\mathrm{x}}$ molecule consumed $\left(\mathrm{O}_{3}\right.$ production efficiency) is more efficient in the aged plume than in the young plume near the city. The major contributor to the high $\mathrm{O}_{3}$ production efficiency in the aged plume is the reaction $\mathrm{RO}_{2}+\mathrm{NO}$. By contrast, the reaction of $\mathrm{HO}_{2}+\mathrm{NO}$ is rather uniformly distributed in the plume.

\section{Introduction}

The export of air pollutants from urban to regional and global environments is of major concern because of wide-ranging potential consequences for human health and for cultivated and natural ecosystems, visibility degradation, weather modification, radiative forcing, and changes in tropospheric oxidation (self-cleaning) capacity. Rapidly increasing urbanization will be a major environmental driving force in the $21 \mathrm{st}$ century, affecting air quality on all scales - local, regional, and global.

The Atmospheric Chemistry Division (ACD) of the National Center for Atmospheric Research (NCAR) has instituted a program called MIRAGE (Megacities Impact on Regional and Global Environments). The goal of MIRAGE is to characterize the chemical/physical transformations and the ultimate fate of pollutants exported from urban areas, and to assess the current and future impacts of these exported pollutants on regional and global air quality, ecosystems, and climate. In March of 2006, ACD led an intensive field campaign called MIRAGE-Mex (Mexico City case study) as part of the MILAGRO (Megacities Initiative: Local And Global Research Observations) project. The MIRAGE-Mex

Published by Copernicus Publications on behalf of the European Geosciences Union. 
campaign integrated observations from ground stations, aircraft, and satellites for Mexico with an emphasis on pollution emanating from the Mexico City plume. This study provided a rich data base for improving regional and global models of the transport and transformations of aging urban pollutants.

The Mexico City metropolitan area is one of the largest megacities in the world, covering $1500 \mathrm{~km}^{2}$ with nearly 20 million inhabitants and including nearly 3.5 million vehicles. The city is located at a high altitude $(2240 \mathrm{~m}$ above sea level) and is in the tropics $\left(19^{\circ} \mathrm{N}\right)$, conditions permitting high solar radiation intensity that leads to rapid formation of ozone and secondary particulate matter. For example, hourly averaged ozone concentrations in the Mexico City Metropolitan Area (MCMA) exceed the Mexican air quality standard of $110 \mathrm{ppb}$ frequently and often exceed twice the standard (Molina and Molina, 2002).

The major focus of MIRAGE-Mex was to study the export of the urban plume to the surrounding area, and to study the evolution of chemical oxidants inside the plume. Tropospheric $\mathrm{O}_{3}$ concentrations are functions of the chain lengths of $\mathrm{NO}_{\mathrm{x}}\left(\mathrm{NO}_{\mathrm{x}}=\mathrm{NO}+\mathrm{NO}_{2}\right)$ and $\mathrm{HO}_{\mathrm{x}}\left(\mathrm{HO}_{\mathrm{x}}=\mathrm{OH}+\mathrm{HO}_{2}+\mathrm{RO}_{2}\right)$ radical catalytic cycles. Thus, $\mathrm{O}_{3}$ formation in a city plume is dependent on ambient levels of $\mathrm{NO}_{\mathrm{x}}$ and volatile organic compounds (VOCs). For example, Zaveri et al. (2003) found, in the 1999 Southern Oxidant study field campaign in Nashville, Tennessee, that the downwind $\mathrm{O}_{3}$ concentrations in the Nashville plume are more sensitive to $\mathrm{NO}_{\mathrm{x}}$ emissions than anthropogenic VOC emissions. By contrast, the study of Kleinman et al. (2003) suggested that $\mathrm{O}_{3}$ production is VOC limited in the high- $\mathrm{NO}_{\mathrm{x}}$ portions of the Philadelphia urban plume. Thielmann et al. (2002) suggested that in the rural area of Milan, Italy, ozone production per $\mathrm{NO}_{\mathrm{x}}$ consumed is less efficient when the advected air masses originate from Milan. This lower efficiency is indicative of VOC-sensitive ozone production. A similar suggestion is also obtained in the New York City plume by Kleinman et al. (2000). Ozone formation in city plumes appears to be strongly dependent local ambient chemical conditions in different regions of the world.

In addition to ambient chemical conditions, ozone concentrations in a city plume are very sensitive to meteorological conditions, including extra-urban scale transport winds, vertical structures of wind fields and mixing processes, and mesoscale convergence zones and transport processes. De Foy et al. (2006) suggested that the residence times in the Mexico City basin are less than $12 \mathrm{~h}$ with little carry-over from day to day and little recirculation of air back into the basin. Very efficient vertical mixing leads to a vertically diluted plume which, in April, is transported predominantly towards the Gulf of Mexico.

Lei et al. (2008) studied the ozone production and response under different meteorological conditions in Mexico City, and Zhang et al. (2009) used the WRF-Chem model to study $\mathrm{O}_{3}$ formation and compared model results to surface measurements. Mena-Carrasco et al. (2008) studied the regional impacts of Mexico City emissions on air quality and chemistry. Their study suggests that the influence of emissions from Mexico City could lead to the enhancements in surface $\mathrm{NO}_{\mathrm{x}}, \mathrm{CO}$, and $\mathrm{O}_{3}$ concentrations to distances of about $200 \mathrm{~km}$. These studies provide useful discussions on the ozone chemistry in the vicinity of Mexico City. In this study, however, the main focus is to investigate the ozone evolution in the downwind plume of Mexico City and the ozone chemical production in air masses with different chemical ages. The model calculation is mainly compared with aircraft observations collected downwind of Mexico City, which were not done in the previous studies.

The WRF-Chem model is used to address scientific questions related to the evolution of ozone and its precursors in the Mexico City plume. The paper is organized as follows: in Sect. 2, we will describe the MIRAGE-Mex flights and data as well as the regional chemical/dynamical model (WRFChem). In Sect. 3, the simulated chemical species will be compared to the measurements of $\mathrm{CO}, \mathrm{O}_{3}, \mathrm{NO}_{\mathrm{y}}, \mathrm{NO}_{\mathrm{z}}\left(\mathrm{NO}_{\mathrm{y}}-\right.$ $\left.\mathrm{NO}_{\mathrm{x}}\right), \mathrm{NO}_{\mathrm{x}}$, and VOC concentrations, so as to evaluate the performance of the model. Section 4 presents model-based estimates of $\mathrm{O}_{3}$ evolution and $\mathrm{OH}$ reactivity related to $\mathrm{O}_{3}$ production due to various processes, and the $\mathrm{O}_{3}$ production efficiency in the city plume downwind of Mexico City.

\section{Data and chemical model}

\subsection{Data}

The MIRAGE- Mex field experiment obtained regional and large-scale measurements up to one thousand kilometers downwind of Mexico City using the C-130 aircraft. During the field experiment, there were a total 12 flights which occurred in 2006 on 4 March (flight 1), 8 March (flight 2), 10 March (flight 3), 12 March (flight 4), 16 March (flight 5), 18 March (flight 6), 19 March (flight 7), 22 March (flight 8), 23 March (flight 9), 26 March (flight 10), 28 March (flight 11), and 29 March (flight 12), respectively. Among the flights, there were some short flights with a $3 \mathrm{~h}$ fly time, such as flight 10 and flight 11 . There were also some flights which were designed to fly over remote regions either to detect a long-range transport plume (more than $1000 \mathrm{~km}$ from the Mexico City) or to measure an intense biomass fire plume, such as the flights 7 and 9. In order to study the evolution of the Mexico City plume, we selected the flights which included Mexico City overpasses as well as downwind plume sampling, with flight duration of $7-10 \mathrm{~h}$. With these selection criteria, flights 2 (8 March), 3 (10 March), 6 (18 March), 8 (22 March), 11 (28 March), and 12 (29 March) are used in this study. Figure 1 shows the tracks for these 6 flights. In this study, when a plume is significantly affected by Mexico City emissions, the plume is defined as a "city plume". Flight-12, was not significantly influenced by the city plume. However, the information during this flight can be considered 

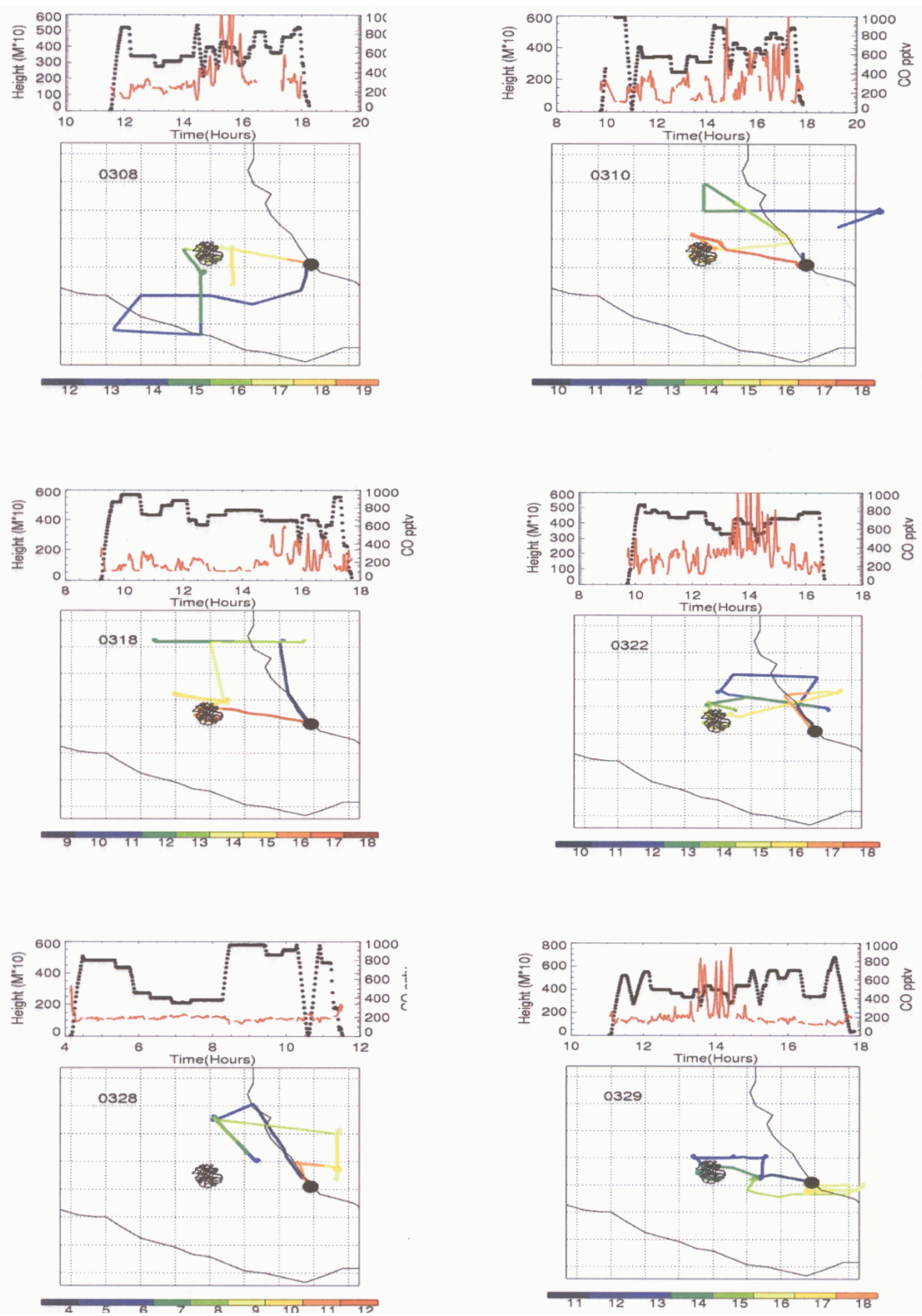

Fig. 1. Flight route information for the flights of 8 March, 10 March, 18 March, 22 March, 28 March and 29 March with 6 panels. Each panel includes upper (altitudes) and lower (horizontal) projections of flight routes. The black and red lines in the upper panels represent the flight altitudes $(\mathrm{km} \times 10)$ and $\mathrm{CO}$ concentrations (ppbv) along the flights. Rapid enhancements of $\mathrm{CO}$ concentrations indicate times when the city plume was detected. The colors in the lower parts show local time during the flights.

as a typical background condition (the plume without the influences by Mexico City emissions), which is used to compare with other flights.

The meteorological conditions during this period were described in detail by Fast et al. (2007), and are briefly summarized here. On 8 March (flight 2), the outflow from the city exhibited a regional cycle pattern, first flowing over the eastern part of the city and later turning southward. The C-130 flight route on this day was located just northeast of the city, followed by city overpasses during the middle of the mission. Thus, some parts of the city plume were detected during the flight. On 10 March (flight 3), the plume was predominantly transported toward the northeast from the city, and the flight was located downwind of the plume. As a result, this flight measured the city plume during a long period of time, especially during the later flight times. On 18 March (flight 6), a 
Table 1. Calculated and measured $\mathrm{CO}, \mathrm{O}_{3}, \mathrm{NO}_{\mathrm{y}}, \mathrm{NO}_{\mathrm{z}}, \mathrm{NO}_{\mathrm{x}}$, VOCs averaged in the city plume and the background conditions in the flight tracks. Xcm, Xcc, $\Delta \mathrm{Xc}(\%), \mathrm{Xbm}, \mathrm{Xbc}, \Delta \mathrm{Xb}(\%), \mathrm{Rcm}, \mathrm{Ym}$, and $\mathrm{Yc}$ represent the mean measured, calculated concentrations, the difference $(\%)$ in the city plumes, the mean measured, calculated concentrations, the difference (\%) in the backgrounds, the correlation $R$, and the ratios for the measured and calculated values between the backgrounds and city plumes.

\begin{tabular}{|c|c|c|c|c|c|c|c|c|c|}
\hline & \multicolumn{6}{|c|}{ Mean concentrations (ppbv) } & \multirow{2}{*}{$\begin{array}{r}\text { Correlation } \\
\text { Rcm }\end{array}$} & \multicolumn{2}{|c|}{ Ratio (bckg/plm) } \\
\hline & $\mathrm{Xpm}$ & $\mathrm{Xpc}$ & $\Delta \mathrm{Xp}(\%)$ & $\mathrm{Xbm}$ & $\mathrm{Xbc}$ & $\Delta \mathrm{Xb}(\%)$ & & Ym & $\mathrm{Yc}$ \\
\hline $\mathrm{CO}$ & 274 & 222 & -18 & 129 & 88 & -31 & 0.93 & 0.47 & 0.40 \\
\hline $\mathrm{O}_{3}$ & 93 & 78 & -16 & 60 & 56 & -7 & 0.92 & 0.65 & 0.71 \\
\hline $\mathrm{NO}_{\mathrm{y}}$ & 9.7 & 5.3 & -43 & 2.0 & 1.2 & -41 & 0.90 & 0.21 & 0.22 \\
\hline $\mathrm{NO}_{\mathrm{Z}}$ & 6.0 & 3.6 & -40 & 1.7 & 1.0 & -40 & 0.71 & 0.28 & 0.28 \\
\hline $\mathrm{NO}_{\mathrm{x}}$ & 3.6 & 1.7 & -52 & 0.35 & 0.17 & -50 & 0.60 & 0.10 & 0.10 \\
\hline Alkane & 15 & 24 & +64 & 1.9 & 1.6 & -16 & 0.97 & 0.12 & 0.07 \\
\hline TOL & 2.19 & 2.2 & +0.4 & 0.27 & 0.16 & -40 & 0.99 & 0.12 & 0.07 \\
\hline $\mathrm{HCHO}$ & 3.8 & 3.5 & -7 & 0.8 & 0.6 & -25 & 0.90 & 0.21 & 0.17 \\
\hline ALD & 3.1 & 4.1 & +32 & 0.7 & 0.51 & -27 & 0.99 & 0.22 & 0.07 \\
\hline
\end{tabular}

trough extending from west to east across the US affected the position of the high pressure system over the Gulf of Mexico and led to variable wind directions over central Mexico. As a result, the flight detected the city plume when the flight passed over the city during later times of the flight. During the earlier part of the flight, the measured $\mathrm{CO}$ concentrations were very low, suggesting that background pollutants were detected during this period. On 22 March (flight 8), there was a plume transported toward the north and northeast from the city. The city plume was well detected by the flight during the middle of the flight, because the majority of the flight routes were located to the northeast of the city. On $28 \mathrm{March}$ and 29 March, there was a persistent high pressure center in central Mexico, producing a northwestern wind. The flight routes of 28 March were mostly located upwind of the plume. As a result, the measured $\mathrm{CO}$ concentrations were generally low. Contrasted with other flights, the measured result during this day can be used as a background pollution state. The flight routes of 29 March were also located mostly far from the plume. However, during the middle of flight, the flight passed over the city, and high $\mathrm{CO}$ values were detected during this short period of time.

During the above 6 flights, $\mathrm{O}_{3}, \mathrm{CO}, \mathrm{NO}, \mathrm{NO}_{2}$, and $\mathrm{NO}_{\mathrm{y}}$ concentrations were continuously measured with 1 second interval. Some volatile organic compounds (VOCs) were measured in-situ with high sampling frequency, while others were obtained more slowly via canister sampling. Some chemical species were unavailable on some flights. For example, $\mathrm{O}_{3}$ was not measured on $18 \mathrm{March}$, and $\mathrm{HCHO}$ was not measured before 18 March. Archived data and related information are available at http://www-air.larc.nasa. gov/cgi-bin/arcstat-b.

\subsection{WRF-Chem model}

An important objective of this study is the intensive use of a regional chemical/dynamical model to compare with the measurements in order to evaluate and eventually improve the model. The evaluated model results are also used to study the chemical evolution of the Mexico City plume. The model used in this study is a recently developed regional chemical/transport model (WRF-Chem, version 2). The Weather Research and Forecasting (WRF) model is a mesocale numerical weather prediction system designed to serve both operational forecasting and atmospheric research needs. The effort to develop WRF has been a collaborative partnership, principally among the National Center for Atmospheric Research (NCAR), the National Oceanic and Atmospheric Administration (NOAA), the National Centers for Environmental Prediction (NCEP), the Forecast Systems Laboratory (FSL), the Air Force Weather Agency (AFWA), the Naval Research Laboratory, Oklahoma University, and the Federal Aviation Administration (FAA). The WRF model is a fully compressible and Euler nonhydrostatic model. The Yonsei University (YSU) PBL scheme (Hong et al., 2006) is used for calculating PBL height in this study. The scheme used the counter-gradient terms to represent fluxes due to non-local gradients, and the entrainment effect is explicitly considered in the scheme. The detailed description of WRF model can be found in the WRF web-site http://www.wrf-model.org/ index.php. In addition to dynamical calculations, a chemical model is coupled on-line with the WRF model (WRFChem). A detailed description of WRF-Chem is given by Grell et al. (2005), and is used here with some modifications in the chemical scheme (Tie et al., 2007). The version of the model, as used in the present study, includes on-line calculation of dynamical inputs (winds, temperature, boundary layer, clouds etc.), transport (advective, convective, and diffusive), dry deposition (Wesely et al., 1989), gas phase chemistry, radiation and photolysis rates (Madronich and Flocke, 1999; Tie et al., 2003a), and surface emissions (including an on-line calculation of biogenic emission). The ozone formation chemistry is represented in the model by 
Table 2. Emissions inventories (tons $\mathrm{yr}^{-1}$ ) for Mexico City.

\begin{tabular}{lrrrr}
\hline & $\mathrm{SO}_{2}$ & $\mathrm{CO}$ & $\mathrm{NO}_{\mathrm{x}}$ & VOCs \\
\hline CIT (Molina and Molina, 2002) & $2.02 \times 10^{5}$ & $3.22 \times 10^{6}$ & $2.02 \times 10^{5}$ & $0.62 \times 10^{6}$ \\
PICCA (Molina and Molina, 2002) & $2.05 \times 10^{5}$ & $2.95 \times 10^{6}$ & $1.77 \times 10^{5}$ & $0.57 \times 10^{6}$ \\
WEST (West et al., 2004) & $2.25 \times 10^{5}$ & $1.77 \times 10^{6}$ & $2.05 \times 10^{5}$ & $1.43 \times 10^{6}$ \\
TIE (Tie et al., 2007) & $0.14 \times 10^{5}$ & $1.73 \times 10^{6}$ & $0.74 \times 10^{5}$ & $1.57 \times 10^{6}$ \\
This study* & $2.50 \times 10^{5}$ & $2.39 \times 10^{6}$ & $1.69 \times 10^{5}$ & $1.23 \times 10^{6}$ \\
\hline
\end{tabular}

* The emissions include other smaller cities outside of Mexico within in $1000 \times 1000 \mathrm{~km}$ domain.

the RADM2 (Regional Acid Deposition Model, version 2) gas phase chemical mechanism (Chang et al., 1989) which includes 158 reactions among 36 species.

In this study, the model resolution measured $6 \times 6 \mathrm{~km}$ in the horizontal direction, in a $900 \times 900 \mathrm{~km}$ domain centered on Mexico City. The lateral chemistry boundary conditions were calculated by a global chemical-transport model (MOZART2 - Ozone and Related chemical Tracers, version 2) (Horowitz et al., 2003). The longer chemical lifetime chemical species (such as $\mathrm{CO}, \mathrm{O}_{3}$, etc.) are exchanged along the boundary condition (including inflow and outflow). The simulation period was from 1 March to 30 March, 2006, and the results along flight tracks were selected for analysis. The emission inventory used in this study for $\mathrm{SO}_{2}, \mathrm{CO}, \mathrm{NO}$, and VOCs are shown in Table 2. In the inventory, beside the emissions from Mexico City, other emissions from small cities in the surrounding area (within the $900 \times 900 \mathrm{~km}$ domain) of Mexico City are also estimated by the assumption that it is proportional to population density. In general, we estimate that the surrounding emissions are smaller than emissions from Mexico City. For example, the emissions of $\mathrm{NO}_{\mathrm{x}}$ from surrounding areas are estimated to be $2.9 \times 104$, which is about $17 \%$ of total emissions. As a result, the emissions from Mexico City dominate the total emissions in the model domain. A comparison with other inventories is also shown in Table 2, and it shows that the $\mathrm{NO}_{\mathrm{x}}$ emission is close to Molina and Molina (2002) and West et al. (2002), and higher than Tie et al. (2007). The VOC emission is close to West et al., but is lower than Tie et al. (2007).

In previous studies, the WRF-Chem model was evaluated by comparing calculated $\mathrm{O}_{3}, \mathrm{CO}$, and $\mathrm{NO}_{\mathrm{x}}$ to the ground measurement from operational monitors in Mexico City (Tie et al., 2007; Ying et al., 2009; Zhang et al., 2009). The model results showed that the magnitude and timing of simulated diurnal cycles of $\mathrm{O}_{3}, \mathrm{CO}$, and $\mathrm{NO}_{\mathrm{x}}$, and the maximum and minimum $\mathrm{O}_{3}$ concentrations were generally consistent with surface measurements. The simulated chemical species concentrations compare favorably with the observations with differences between calculated and measured values of 10 $30 \%$. However, there was no systematic comparison of the model result with the MILAGRO field campaign, and this will be a focus point in this study.

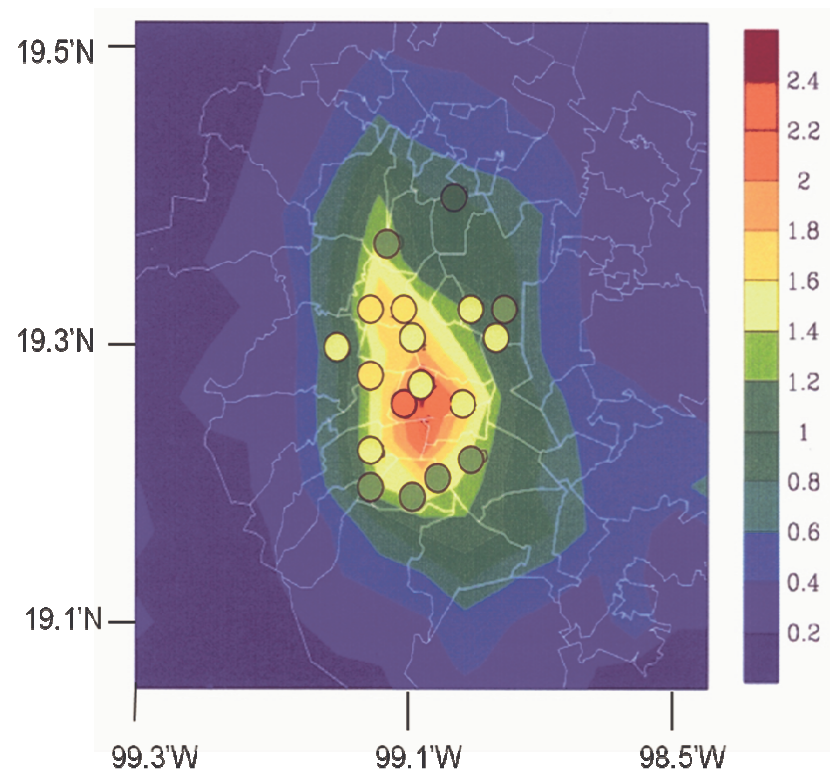

Fig. 2. Calculated and measured surface CO concentrations (ppmv) averaged during the 6 flight periods. The contour lines are calculated values, and the color dots are measured values.

\section{Model calculations}

\subsection{Transport evaluation for calculated $\mathrm{CO}$ at surface and in the plume}

In order to evaluate model calculations of ozone production in the city plume, one important aspect is to understand the transport of the model from the surface and the planetary boundary layer (PBL) to the free troposphere. In this study, we use the calculated $\mathrm{CO}$ both at the surface and in the plume aloft to evaluate the model transport. The chemical lifetime of $\mathrm{CO}$ is of order of months, thus over the few days relevant here it can be considered as a passive tracer which is emitted from the surface, mixed in the PBL, and transported with prevailing winds. 


\subsubsection{Evaluation of calculated surface $\mathrm{CO}$}

The surface $\mathrm{CO}$ concentrations in the Mexico City have been monitored routinely since 1986 by the local air quality monitoring network (RAMA) (Molina and Molina, 2002). In the first step of the evaluation, the calculated surface $\mathrm{CO}$ concentrations are compared with the measured $\mathrm{CO}$ concentrations of this network to get some insight of modeled $\mathrm{CO}$ emissions and transport processes in the PBL of Mexico City. Figure 2 shows the average $\mathrm{CO}$ concentrations in Mexico City during the 6 flight days $(8,10,18,22,28$, and 19 in March). The comparison between calculated and measured spatial distribution of $\mathrm{CO}$ concentrations shows that the calculated $\mathrm{CO}$ concentrations are generally consistent with observations. For example, both the calculated and measured CO concentrations are higher in the center of the city with a value near 2 ppmv, and decrease toward the edge of the city to a value of 1.0 ppmv. However, discrepancies between the calculation and measurement are also evident. The calculated $\mathrm{CO}$ concentrations are slightly higher than the measured values in the south of the city by about 0.2 to 0.4 ppmv. Figure 3 shows the comparison between calculated and measured diurnal cycles of $\mathrm{CO}$ concentrations averaged over all urban surface stations. Peak morning values of $\mathrm{CO}$ in both the calculated and measured results range from 3 to 5 ppmv. The calculated minimum $\mathrm{CO}$ concentrations during noontime are also consistent with the measured concentrations with values of about 1 ppmv. However, it is evident that the calculated $\mathrm{CO}$ concentrations are overestimated in the evening. The overestimated values are highest on 8 March and lowest on 28 March, highlighting that there is a strong variability during different days. As suggested by Tie et al. (2007), the diurnal variation of surface $\mathrm{CO}$ concentrations is mainly controlled by the daily variability of PBL height and emission of CO. In the early morning, emissions rapidly increase mainly due to an increase in mobile (vehicular) emissions, while the PBL is still shallow. As a result the emitted $\mathrm{CO}$ is confined near the surface, producing high $\mathrm{CO}$ concentrations. As morning progresses, the $\mathrm{PBL}$ height increases allowing rapid dilution of $\mathrm{CO}$ concentrations. In the evening, the peak $\mathrm{CO}$ concentrations occur again as a result of increase in emissions and a slowing of PBL mixing. Because there are no day to day variations of emission of $\mathrm{CO}$ in the model, the strong variation in different days is mainly due to the variability of different diurnal patterns of the PBL heights, suggesting that the decrease in the PBL height in the evening (especially for 8 March) is faster in the model than the real situation. As a result, freshly emitted $\mathrm{CO}$ is retained in a shallow PBL, resulting in an overestimation of the surface CO concentrations. On 18 March, the calculated PBL height during evening time is better represented, and the overestimated surface $\mathrm{CO}$ concentrations are reduced. Overall, the calculated spatial distributions and magnitudes of surface $\mathrm{CO}$ concentrations are generally consistent with the measured values. The calculated diurnal variations are consistent with

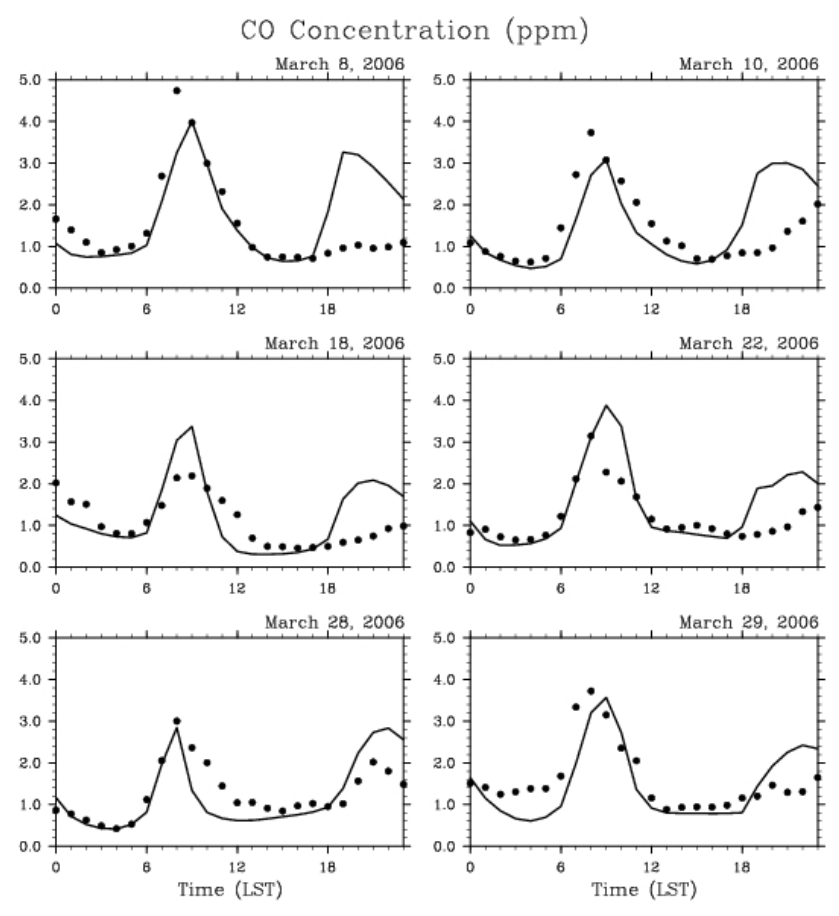

Fig. 3. Calculated (lines) and measured (dots) diurnal cycles of surface CO (ppmv) averaged over all RAMA stations for each of the flight days.

the measured results during morning and noontime, but overestimated during evening. The evaluation of the PBL was conducted in the study of Zhang et al. (2009) using the WRFChem model in Mexico City. Their study suggested that the observed and simulated PBL heights agree reasonably well in terms of magnitude and temporal variations during noon time. However, the simulated PBL height is low and less variabile during night compared to the PBL height observed by radiosonde. The calculated shallow PBL height could lead to higher surface concentrations during night (Tie et al., 2007).

Figure 4 shows an overall comparison of daily average $\mathrm{CO}$ concentrations of the model with measured values. The results indicate the discrepancies (model - measurement) of CO surface concentrations range from -6 to $+20 \%$, with an average discrepancy of about $+6 \%$. Note that the emissions used in the model did not take into account the weekend effect (the emissions are generally smaller during weekend than weekdays). As a result, the overestimation on 18 March could partially due to neglecting the reduction of weekend emissions in the model.

\subsubsection{Evaluation of calculated $\mathrm{CO}$ plumes}

The calculation of $\mathrm{CO}$ concentrations in the plumes is more complex than the calculation of its surface concentrations. The major determining factors for calculating the surface 


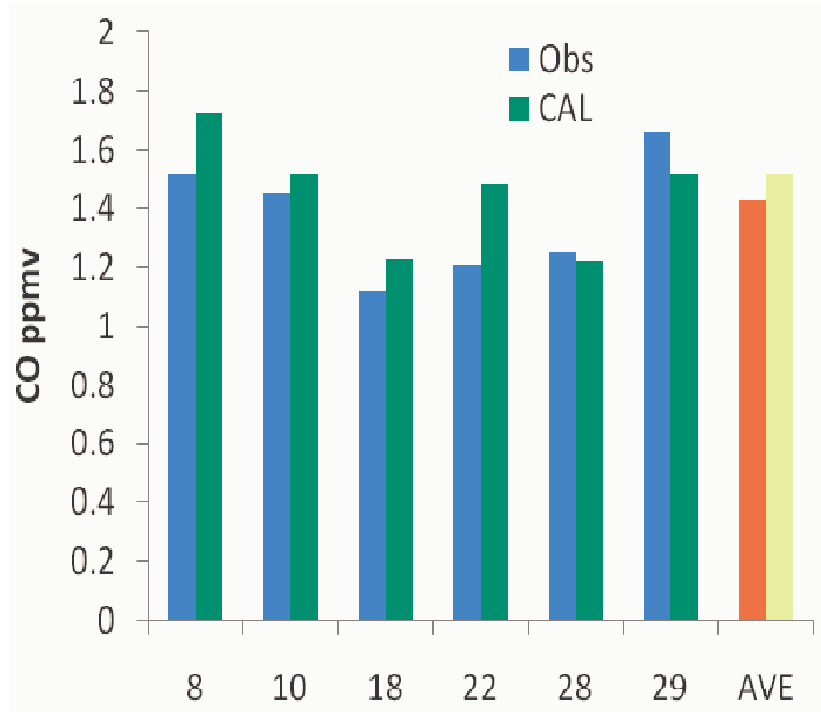

Fig. 4. Comparison of calculated (green) and measured (blue) surface $\mathrm{CO}$ concentrations averaged over each day. The red and yellow bars represent measured and calculated values averaged over all flight days.

concentrations are surface emissions and mixing in the PBL (Tie et al., 2007). For calculating plume CO levels, additional factors must be considered including the transport of CO across the PBL and the calculation of the prevailing winds. The upper panels of Fig. 5 show that the calculated $\mathrm{CO}$ has a variability that is broadly consistent between the model and observations for all the flights. For example, during the flight of 10 March, the city plume (high CO concentrations) is detected between 1500 and $1700 \mathrm{~h}$ with a large variation. The calculated $\mathrm{CO}$ variability during this period is similar to the measured results, showing the capability of the model in capturing this highly variable city plume. Another example is shown during the flight of 29 March, where both observations and model show evidence of high $\mathrm{CO}$ concentrations in the city plume for a short time (from 13:30 to $14: 30$ p.m.) with values rapidly increasing from background (about $100 \mathrm{ppbv}$ ) to about $600 \mathrm{ppbv}$. By contrast, the flight route of 28 March is mostly located upwind of the city and both calculation and measurement show very low CO concentrations, as no city plumes are detected. The flight of 28 March is included in this study to get some insights regarding the background atmosphere. The background concentrations in this study refer to the concentrations without significant effect from Mexico City. As we described before the model lateral boundaries allow the exchanges between other regions of world and the model domain for air pollutants with longer chemical life time (such as $\mathrm{CO}, \mathrm{O}_{3}$, etc.). However, the emissions from other parts of the world are included in the background concentrations, but are largely diluted, contributing relatively little to the averaged conditions.

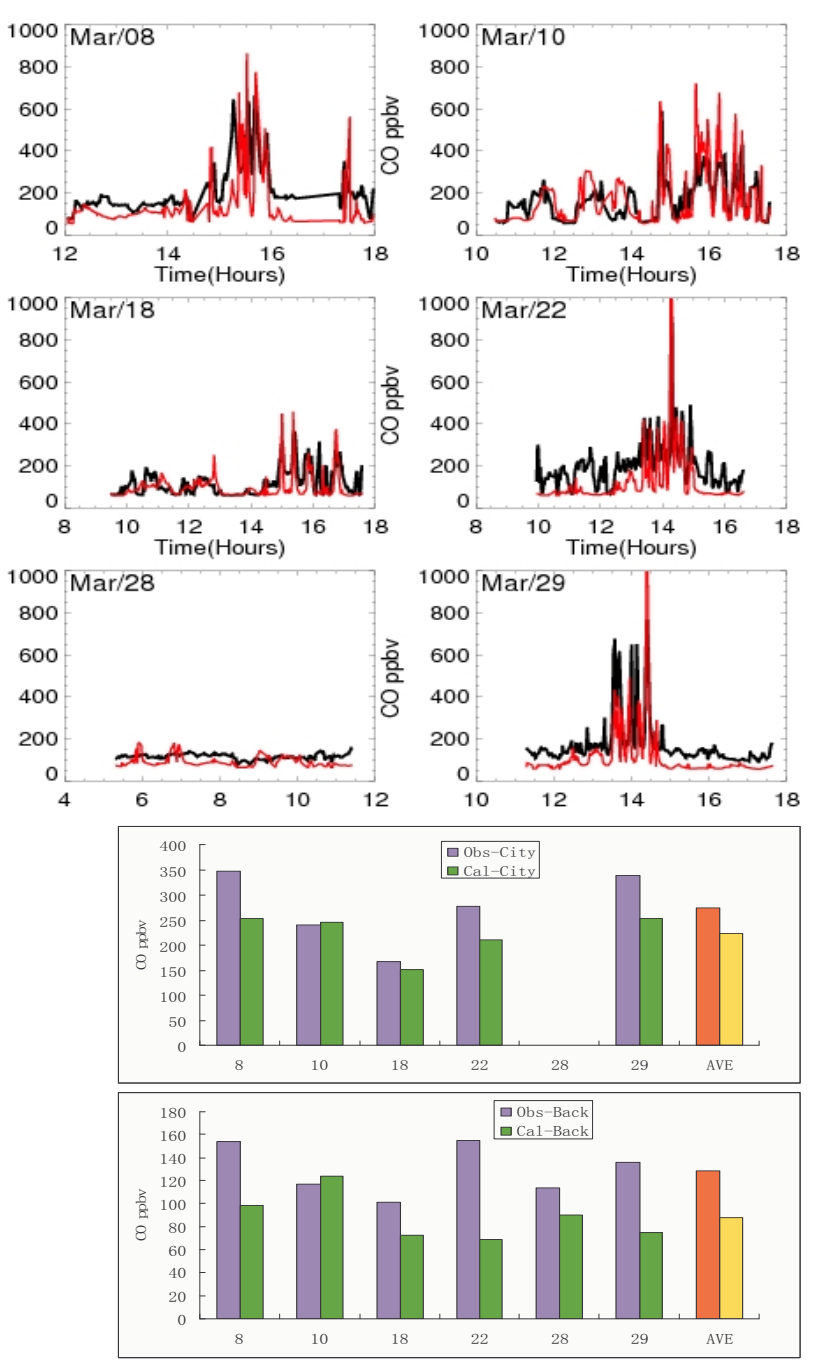

Fig. 5. Calculated (red lines) and measured (black lines) CO concentrations along the 6 flights (upper panel). The middle panel shows the averaged $\mathrm{CO}$ concentrations in the city plumes (see text for city plume definition), and the lower panel shows the averaged $\mathrm{CO}$ concentrations in the background conditions. The blue and green bars represent for the measured and calculated values during each flights. The red and yellow bars represent for the measured and calculated values averaged for the all flights.

In these 6 flights, city plumes are detected on 8 March, 10 March, 18 March, 22 March, and 29 March. To get more detailed estimates for the calculated city plume, in the following sections we will separate the concentrations into 2 categories in the 6 flights, including (a) the averaged values to represent the city plumes and (b) the averaged values to represent the background values in both the calculation and measurement during each of the flights. The criterion for a city plume encounter is either that a flight path passes directly over the city or through the downwind plumes as determined by rapidly increasing measured $\mathrm{CO}$ concentrations 

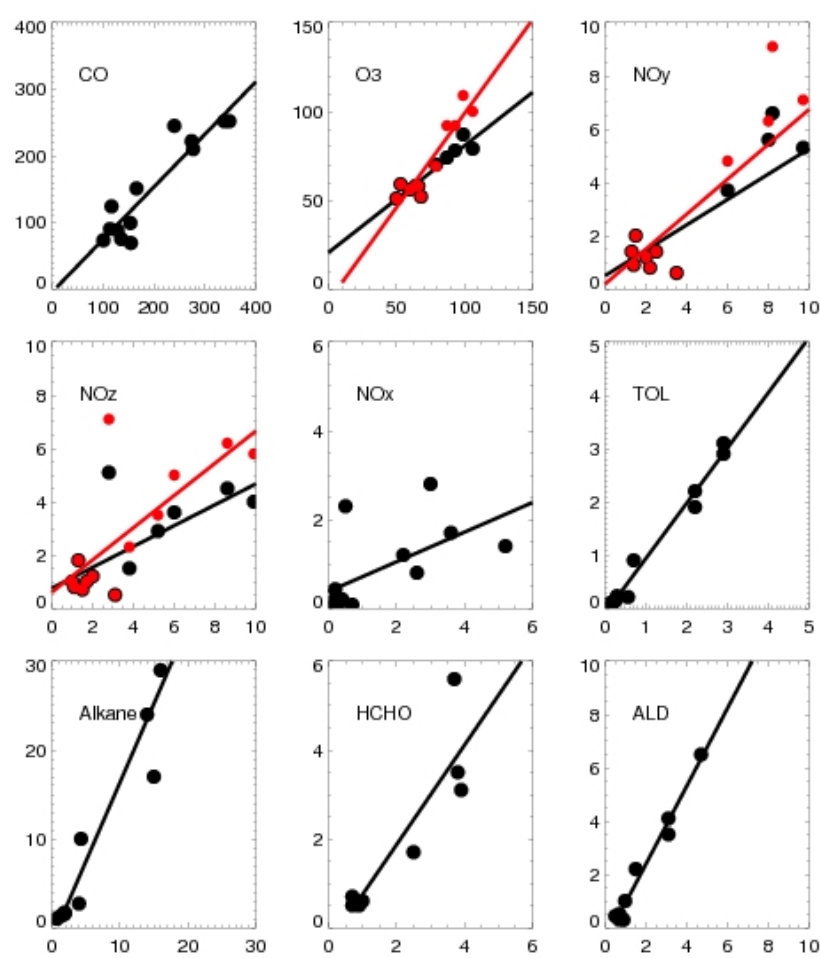

Fig. 6. Comparison of observed (x-axis) and calculated (y-axis) concentration of $\mathrm{CO}, \mathrm{O}_{3}, \mathrm{NO}_{\mathrm{y}}, \mathrm{NO}_{\mathrm{z}}, \mathrm{NO}_{\mathrm{x}}$, toluene, alkanes, $\mathrm{HCHO}$, and aldehydes along C-130 flight tracks. Each point represents the averaged values in the city plume or background air during each flight. The red line and dots represent adjusted values by using Eq. (1).

as indicated in Fig. 1. Otherwise, it is considered as the background condition. This criterion is also applied for other species (such as $\mathrm{O}_{3}, \mathrm{NO}_{\mathrm{y}}, \mathrm{NO}_{\mathrm{x}}$, and VOCs) which showed elevated values correlated with the $\mathrm{CO}$ plumes. Based on this separation, the lower panels of Fig. 5 show that the averaged $\mathrm{CO}$ concentrations in the city plumes range from 200 to $350 \mathrm{ppbv}$ and the averaged background $\mathrm{CO}$ concentrations range from 100 to 150 ppbv. The calculated $\mathrm{CO}$ concentrations in both the city plumes and in the backgrounds are systematically lower than the measured values. For example, the differences between the calculated and measured $\mathrm{CO}$ concentrations in the city plumes are $-27,2,-9,-24$, and $-25 \%$ for the flights on 8 March, 10 March, 18 March, 22 March, and 29 March, respectively. The averaged difference is $-18 \%$. As described before, the calculated surface CO concentrations are generally consistent with the measured values, and even slightly higher than the measurements. The systematic underestimates of the $\mathrm{CO}$ concentrations in the city plume suggest that the model is underestimating dispersion processes from the surface to the plume levels (sometimes in the PBL and sometimes outside of the PBL), and possibly overestimating mixing with cleaner background air. As a result, this underestimation is likely a systematic trans- port error for which some adjustment can be made. In the following sections, this transport error is applied to other chemical species that have a fairly long lifetime (such as $\mathrm{O}_{3}$, $\mathrm{NO}_{\mathrm{y}}, \mathrm{NO}_{\mathrm{z}}$, etc.) to get adjusted values. The adjusted values can reduce this transport error, and provide insights for other sources of errors (such as emission, etc.). An adjusted concentration for species $(X)$ in the plumes during different flights can be calculated by the following method:

$X \_\operatorname{adj}(i)=X(i) *[(1+A(i) / 100)]^{-1}$

where $X(i)$ represents the modeled un-adjusted plume concentration of a chemical species (such as $\mathrm{NO}_{\mathrm{y}}$ ) during the $i^{\text {th }}$ flight (for example, flight of 8 March); $X_{-} \operatorname{adj}(i)$ represents the adjusted concentration of the chemical species; $A(i)$ represent an adjustment factor due to underestimates of the transport from the surface to the city plumes in different flights. According to the above study of $\mathrm{CO}$, the factors are $27,-2,9,24$, and $25 \%$ for the flights of 8 March, 10 March, 18 March, 22 March, and 29 March, respectively. We should mention that beside the dispersion uncertainty, other errors also can be introduced in the model simulations, such as the uncertainties associated with emissions, PBL height etc. The above correction factor can only provide an estimate of the errors related to the dispersion process, instead of an accurate calculation.

\subsection{Evaluation of $\mathrm{O}_{3}$ concentration during the flights}

The in-situ comparison of the calculated $\mathrm{O}_{3}$ (and other species) to the measured values along the flight tracks suggests that the model is capable of capturing the variability of $\mathrm{O}_{3}$, showing a rapid enhancement when city plumes are detected. In the following sections, we will show the one by one comparisons between the calculated and measured mean values in both the city plumes and in the background during different flights. This comparison illustrates the systematic bias of the calculations, and the correlations between the calculations and measurements.

Figure 6 shows the one by one comparison for $\mathrm{O}_{3}$ and other species. Table 1 gives the calculated and measured mean values in both the city plumes and background, and also correlations between the calculated and measured values, and ratio between the background and city values. The results suggest that the calculated $\mathrm{O}_{3}$ is consistently underestimated in both the city plumes and in the background compared to the measured $\mathrm{O}_{3}$ concentrations. The averaged underestimates are $16 \%$ in the city plumes, and $7 \%$ in the background. One reason for the underestimates of $\mathrm{O}_{3}$ concentrations is attributed to the underestimates of the transport processes. The effect of these underestimates can be reduced by application of Eq. (1) to get adjusted $\mathrm{O}_{3}$ concentrations. However, $\mathrm{CO}$ is determined mostly by transport, but $\mathrm{O}_{3}$ also depends non-linearly on $\mathrm{NO}_{\mathrm{x}}$. Before applying Eq. (1), the relationship between $\mathrm{D}[\mathrm{CO}]\left(\mathrm{CO}_{\mathrm{CAL}}-\mathrm{CO}_{\mathrm{MEA}}\right)$ and $\mathrm{D}\left[\mathrm{O}_{3}\right]$ $\left(\mathrm{O}_{3 \mathrm{CAL}}-\mathrm{O}_{3 \text { MEA }}\right)$ needs to be examined. $\mathrm{D}[\mathrm{CO}]$ and $\mathrm{D}\left[\mathrm{O}_{3}\right]$ 


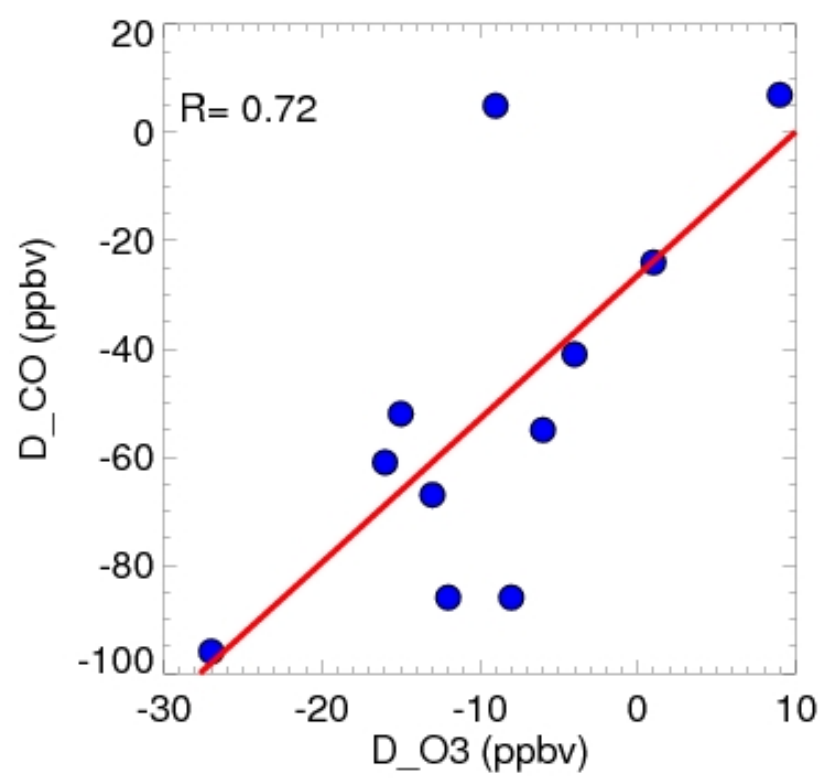

Fig. 7. Comparison of model-measurement differences for $\mathrm{CO}$, $\mathrm{D}[\mathrm{CO}]=\mathrm{CO}_{\mathrm{CAL}}-\mathrm{CO}_{\mathrm{MEA}}$, and $\mathrm{D}\left[\mathrm{O}_{3}\right]=\mathrm{O}_{3 \mathrm{CAL}}-\mathrm{O}_{3} \mathrm{MEA}$. Each point represents the averaged values in the city plume or background air during each flight.

represent the discrepancies between the calculated and measured $\mathrm{CO}$ and $\mathrm{O}_{3}$ during different flights. If the discrepancies in $\mathrm{CO}$ and $\mathrm{O}_{3}$ are positively correlated, the underestimates of $\mathrm{O}_{3}$ are at least partly attributable to the transport error. Figure 7 shows that $\mathrm{D}[\mathrm{CO}]$ and $\mathrm{D}\left[\mathrm{O}_{3}\right]$ are correlated with a correlation coefficient of 0.7 . Thus, the adjustment for $\mathrm{O}_{3}$ concentrations can be applied by using Eq. (1). After this adjustment, the difference between the calculated and measured $\mathrm{O}_{3}$ concentrations is improved (see Fig. 6) from about $16 \%$ to $1 \%$, which suggests that the underestimates of $\mathrm{O}_{3}$ concentrations in the city plumes is largely a result of the underestimates of the transport from the surface to the city plumes. At present, due to limitations of the computation capability, the chemical scheme used in regional models are all simplified to some degree for ozone calculations, e.g., WRF-Chem (RADM scheme) and CAMx (SAPRC-99 scheme) (Lei et al., 2008). However, even though both the models use simplified chemical schemes, the basic ozone chemistry is well represented as shown by comparisons with the surface measured ozone values. Both the model results showed that in Mexico, the ozone chemical production is in VOC-limited regime, while in the rural areas, the ozone chemical production is in $\mathrm{NO}_{\mathrm{X}}$-limited regime.

\subsection{Evaluation of nitrogen species during the flights}

The evaluated nitrogen species in this study include $\mathrm{NO}_{\mathrm{x}}$ $\left(\mathrm{NO}+\mathrm{NO}_{2}\right), \mathrm{NO}_{\mathrm{y}}$ (all nitrogen species), and $\mathrm{NO}_{\mathrm{z}}\left(\mathrm{NO}_{\mathrm{y}}-\right.$ $\mathrm{NO}_{\mathrm{x}}$ ). The model captures the timing/location of the city plume as well as the strong variability seen in the measurements (not shown). However, the calculated $\mathrm{NO}_{\mathrm{y}}$ concentrations are consistently smaller than the measured $\mathrm{NO}_{\mathrm{y}}$ concentrations in both the city plumes and the backgrounds. The averaged underestimates are $40 \%$ in the city plumes, and $40 \%$ in the backgrounds (see Fig. 6 and Table 1). One of the reasons for the underestimates of the city plume concentrations is related to the large underestimates of the background values (by about $0.8 \mathrm{ppbv}$ ). Another reason results from the underestimation in the transport from the surface to the downwind plumes, as already discussed for $\mathrm{CO}$. In order to take into account this transport underestimate, Eq. (1) is applied for the $\mathrm{NO}_{\mathrm{y}}$ concentrations in the city plumes. With this consideration, the underestimates of $\mathrm{NO}_{\mathrm{y}}$ concentrations in the city plumes reduce from 40 to $30 \%$. Furthermore, if the underestimates of the background $\mathrm{NO}_{\mathrm{y}}$ concentrations (with an averaged value of $0.8 \mathrm{ppbv}$ ) are added in to the calculated $\mathrm{NO}_{\mathrm{y}}$ concentrations, the underestimates of plume $\mathrm{NO}_{\mathrm{y}}$ concentrations decrease from 30 to about $20 \%$. This remaining underestimate may then be mainly attributed to uncertainties in surface emissions of $\mathrm{NO}_{\mathrm{x}}$.

As suggested by Godowitch et al. (2008) and Fischer et al. (2003), $\mathrm{NO}_{\mathrm{z}}\left(\mathrm{NO}_{\mathrm{y}}-\mathrm{NO}_{\mathrm{x}}\right)$ concentrations and the correlation between $\mathrm{NO}_{\mathrm{z}}$ and $\mathrm{O}_{3}$ are good indicators for the rate of $\mathrm{O}_{3}$ production in differently aged city plumes. Thus, the calculated $\mathrm{NO}_{\mathrm{z}}$ concentrations are evaluated by comparing to the measured $\mathrm{NO}_{\mathrm{z}}$ concentrations in the flights (shown in Fig. 6 and Table 1). The results suggest that the simulated $\mathrm{NO}_{\mathrm{z}}$ variability is consistent compared with the measured results. High concentrations of $\mathrm{NO}_{\mathrm{z}}$ are seen in the city plumes, while during the flight of 28 March (background case) both the calculated and measured $\mathrm{NO}_{\mathrm{z}}$ concentrations are low with concentrations near $1.0 \mathrm{ppbv}$. However, the calculated $\mathrm{NO}_{\mathrm{z}}$ concentrations are consistently smaller than the measured concentrations in both the city plumes and backgrounds. The calculated $\mathrm{NO}_{\mathrm{z}}$ concentrations in the city plumes are underestimated by $40 \%$. Because $\mathrm{NO}_{\mathrm{z}}$ is a longlived chemical species like $\mathrm{NO}_{\mathrm{y}}$, there is a possibility that the underestimate is also partially resulting from the underestimate of transport from the surface to the city plume. After Eq. (1) is applied for the $\mathrm{NO}_{\mathrm{z}}$ concentrations in the city plumes, the underestimates of $\mathrm{NO}_{\mathrm{z}}$ concentrations in the city plumes reduces to $28 \%$. Furthermore, if the underestimate of the background $\mathrm{NO}_{\mathrm{z}}$ concentrations (with an averaged value of $0.7 \mathrm{ppbv}$ ) is added in the calculated $\mathrm{NO}_{\mathrm{z}}$ concentrations in the city plumes, the underestimate of $\mathrm{NO}_{\mathrm{z}}$ concentrations reduces to $17 \%$, which is generally the same error shown in the $\mathrm{NO}_{\mathrm{y}}$ calculations.

The calculated $\mathrm{NO}_{\mathrm{x}}$ concentrations have a stronger variability than the calculated $\mathrm{CO}, \mathrm{O}_{3}$, and $\mathrm{NO}_{\mathrm{y}}$. The enhancement of $\mathrm{NO}_{\mathrm{x}}$ concentrations in the city plumes is much higher than the $\mathrm{NO}_{\mathrm{y}}$ concentrations. For example, the ratios between background concentrations and city plume concentrations and are 0.2 and 0.1 for $\mathrm{NO}_{\mathrm{y}}$ and $\mathrm{NO}_{\mathrm{x}}$, respectively. Unlike $\mathrm{CO}$ and $\mathrm{NO}_{\mathrm{y}}, \mathrm{NO}_{\mathrm{x}}$ has a very short chemical 
lifetime (from hours to days) (Ridley et al., 1996; Tie et al., 2006). Because there are rapid and complex chemical reactions inside the city plumes, the calculation of $\mathrm{NO}_{\mathrm{x}}$ in the city plumes is more difficult than the less reactive species, such as $\mathrm{CO}$ and $\mathrm{NO}_{\mathrm{y}}$. As a result, a large variability occurs for the $\mathrm{NO}_{\mathrm{x}}$ calculations. For example, during the flight of 10 March, the calculated $\mathrm{NO}_{\mathrm{x}}$ concentrations are close to the measured values with a difference of $7 \%$. However, during the flight of 29 March, the calculated $\mathrm{NO}_{\mathrm{x}}$ concentrations are underestimated by $70 \%$ (not shown). In general, the calculated $\mathrm{NO}_{\mathrm{x}}$ concentrations are consistently underestimated for all flights, with an averaged underestimate of $50 \%$. The underestimate is partially due to the underestimate of surface emissions of $\mathrm{NO}_{\mathrm{x}}$ as suggested by the $\mathrm{NO}_{\mathrm{y}}$ analysis (about 20\% underestimation of surface emissions). However, the large variability in calculated $\mathrm{NO}_{\mathrm{x}}$ errors during different flights suggests that the calculated errors are also attributed to the complication of the interaction between fast chemical reactions and transport processes from the surface to the plumes as well as the uncertainties related to the simulations of timing of spatial positions of the city plumes.

\subsection{Evaluation of VOC species during the flights}

As suggested by Sillman (1995), VOCs are considered as the initiators for the ozone production process. In VOC-limited regions, the amounts of VOCs are a crucial factor in controlling the rate of $\mathrm{O}_{3}$ production. Because there are different types of VOCs, the rate of ozone production is not only determined by the concentrations of VOCs, but also the rate of oxidation of VOCs. Most VOCs are first oxidized, mainly by $\mathrm{OH}$ with a rate coefficient of $k_{\mathrm{OH}+X}$. The reactivity of $\mathrm{OH}$ with various $\mathrm{VOC}$ compounds $[X]$, i.e. $k_{\mathrm{OH}+X}[X]$, is a key parameter to determine the contributions of an individual VOC to the rate of $\mathrm{O}_{3}$ production. For example, alkane species generally react with $\mathrm{OH}$ more slowly than do aromatics, but their concentrations are normally higher than aromatics in citiesAs a result, both VOC classes could be important for ozone productions in the city plumes. Although VOC reactions are generally numerous and complex, the chemical scheme of WRF-Chem (RADM2) simplifies the VOC reactions into a relatively smaller set. For example, several alkane species are lumped into one alkane with a mean reaction rate. Thus, some assumptions are needed to match the calculated VOC species to measured VOC species. According to the availability and reliability of the VOC data collected in the aircraft, the following VOC species are evaluated in the model calculation, i.e. a surrogate alkane (alkanes with $\mathrm{OH}$ reaction coefficient less than $6.8 \times 10^{-12}$ ), an aromatic species (toluene), and oxygenated VOC species (HCHO and higher aldehydes).

The calculated toluene concentrations are in good agreement with the measured values (see Fig. 6). The enhanced concentrations in the city plume are well captured. The averaged calculated and measured toluene concentrations in the city plume are 2.2 and $2.1 \mathrm{ppbv}$, respectively. The correlation coefficient between the calculated and measured values is 0.99 (see Table 1). Background concentrations are very low, suggesting that toluene originates mainly from urban emissions, and the high concentrations in the city plumes decrease rapidly due to fast reaction with $\mathrm{OH}$. The ratio between the background and city is about 0.12 .

As described above, the alkane in the WRF-Chem model is a surrogate compound with an $\mathrm{OH}$ reaction coefficient of less than $6.8 \times 10^{-12}$. As a result, the measured alkane species which have a reaction coefficient of $<6.8 \times 10^{-12}$ were summed for comparison with the surrogate alkane (Fig. 6 and Table 1). The results suggest that the calculated alkane is consistently higher than the measured values, showing a strong urban enhancement. The averaged alkane concentrations for the calculations and measurements in the city plumes are 24 and 15 ppbv, respectively. However, the calculated background alkane concentrations are generally closer to the measured values, respectively 1.6 and $1.9 \mathrm{ppbv}$,. The overestimated alkane concentrations in the city plumes are likely attributed to the overestimate of the surface emission of alkanes in the model, because this difference cannot be explained by the transport adjustment or errors in background concentrations.

Unlike the alkanes and toluene, which are primarily emitted from the surface, the oxygenated VOCs (OVOCs, such as $\mathrm{HCHO}$ and higher aldehydes) are not only emitted, but also chemically produced in the plumes. As a result, the OVOCs could play relatively more important roles in $\mathrm{O}_{3}$ production in the downwind region of plumes. The result shows that the calculated HCHO concentrations are slightly underestimated during the flights of 18 March and 22 March, but are overestimated during the flight of 29 March. The averaged concentrations for the calculations and the measurements are 3.5 and $3.8 \mathrm{ppbv}$ in the city plumes, with about $7 \%$ underestimate. The background concentrations are also slightly underestimated, with averaged concentrations of 0.6 and $0.8 \mathrm{ppbv}$ for the calculations and measurements, respectively. The correlation coefficient between the calculated and measured values is relatively high, with a value of 0.90 .

Acetaldehyde is another important OVOC species is, having a reaction rate with $\mathrm{OH}$ that is higher than the corresponding rate rate for $\mathrm{HCHO}$. In the city plumes, the measured aldehyde concentration is $3.1 \mathrm{ppbv}$, which is comparable with the measured value of HCHO (3.8 ppbv). With a higher reaction rate, acetaldehyde could play a relatively more important role in $\mathrm{O}_{3}$ production in downwind region of plumes. The calculated acetaldehyde concentrations in the city plumes are overestimated compared to the measured values. However, the calculated background aldehyde concentrations are slightly underestimated compared with the measured values. The averaged concentrations for the calculations and the measurements are 4.1 and $3.1 \mathrm{ppbv}$ in the city plumes, respectively. The averaged background concentrations are 0.51 and $0.70 \mathrm{ppbv}$ for the calculations and mea- 

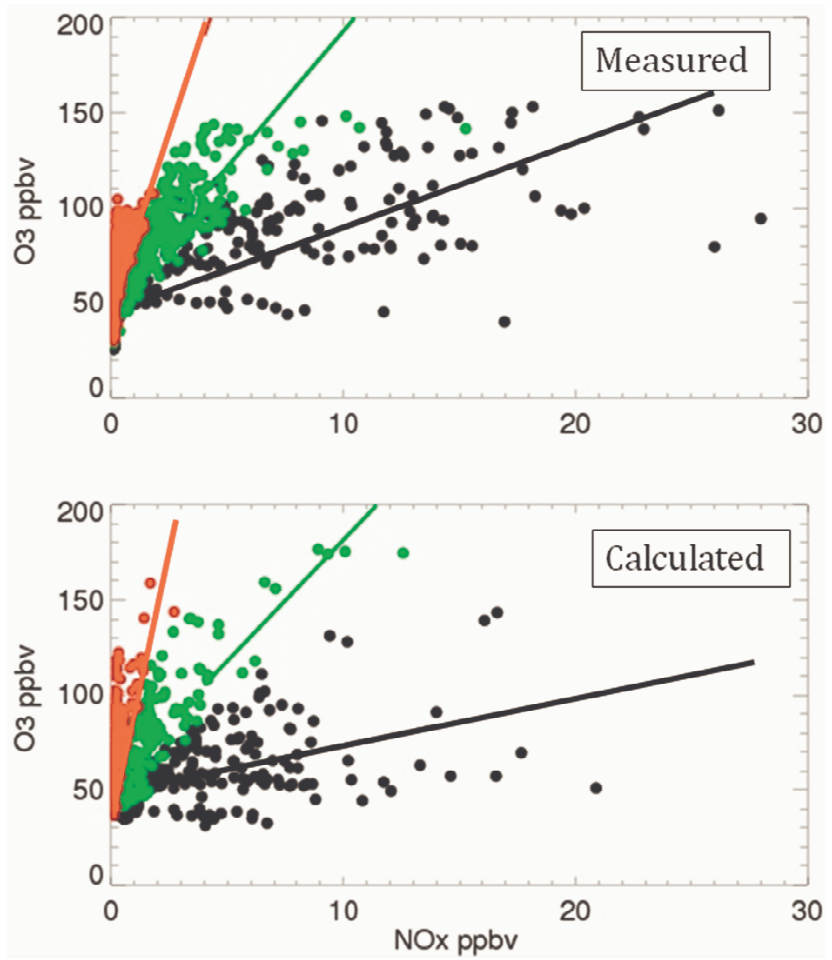

Fig. 8. Measured (upper panel) and calculated (lower panel) $\mathrm{O}_{3}-$ $\mathrm{NO}_{\mathrm{x}}$ correlation with different ages of the plume. The black, green, and red (dots and lines) present the young age (AG-1), middle age (AG-2), and old age (AG-3) plumes, respectively. The lines used the first-order polynomial fits for measured and modeled results.

surements, respectively. The correlation between the calculated and measured values is very good, with a coefficient of 0.99 .

\section{Analysis of the $\mathrm{O}_{3}$ production in the plumes}

The production of $\mathrm{O}_{3}$ depends non-linearly on the concentrations of precursors $\left(\mathrm{NO}_{\mathrm{x}}, \mathrm{CO}\right.$, primary VOCs and secondary VOCs) (Kleinman et al., 2000). As a concentrated city plume leaves from city and the primary chemicals start to be diluted, the $\mathrm{O}_{3}$ production rate and efficiency is expected to vary non-linearly. Furthermore, the concentrations of oxygenated VOCs (such as $\mathrm{HCHO}$ and other aldehydes) are continuously produced and destroyed in the downwind of the Mexico City plume. Because the OVOCs are also important $\mathrm{O}_{3}$ precursors (Singh et al., 1995; Apel et al., 2008), OVOC oxidations lead to additional $\mathrm{O}_{3}$ production along plumes. In this study, we will focus on 3 issues regarding $\mathrm{O}_{3}$ production along the Mexico City plume; (1) what is the $\mathrm{O}_{3}$ production behavior at different ages of the plume; (2) what is the $\mathrm{O}_{3}$ production efficiency (molecules of $\mathrm{O}_{3}$ produced per $\mathrm{NO}_{\mathrm{x}}$ molecule consumed) in different plume ages; and (3) what are the roles of different $\mathrm{O}_{3}$ precursors (such as $\mathrm{CO}$, alkanes, OVOCs, etc.) in the $\mathrm{O}_{3}$ production in different ages of the plumes. First, we define the chemical "age" of plume.

\subsection{Chemical age of the city plume}

In order to chemically characterize the Mexico City plume in different age regimes, the chemical age of the city plume is defined by Kleinman (2008) and is expressed by;

$A G=-\operatorname{Ln}\left(\mathrm{NO}_{\mathrm{x}} / \mathrm{NO}_{\mathrm{y}}\right)$

The conversion from $\mathrm{NO}_{\mathrm{x}}$ to $\mathrm{NO}_{\mathrm{y}}$ results mainly from the reactions of $\mathrm{NO}_{\mathrm{x}} \rightarrow \mathrm{HNO}_{3}$ and $\mathrm{NO}_{\mathrm{x}} \rightarrow$ organic nitrates. In addition, there is also an important pathway to convert $\mathrm{NO}_{\mathrm{x}}$ to $\mathrm{NO}_{\mathrm{y}}$ through the hydrolysis of $\mathrm{N}_{2} \mathrm{O}_{5}$ on the sulfate aerosols. However, this later reaction becomes important only when sulfate aerosol loading is high and solar radiation is low (e.g., at high latitudes or during nighttime) (Tie et al., 2003b, 2005). In Mexico City, the later reaction to convert $\mathrm{NO}_{\mathrm{x}}$ to $\mathrm{NO}_{\mathrm{y}}$ can be neglected. In some of the following discussion, we will define plumes as young, middle-aged, or old depending on whether the value of $A G$ is $0-1,1-2$, or larger than 2 , respectively.

\section{2 $\mathrm{O}_{3}$ and $\mathrm{NO}_{\mathrm{x}}$ relationship}

Ozone precursors such as $\mathrm{CO}, \mathrm{NO}_{\mathrm{x}}$, and VOCs are found to be closely correlated to $\mathrm{O}_{3}$ concentrations. First, we will show the $\mathrm{O}_{3}-\mathrm{NO}_{\mathrm{x}}$ correlation with different chemical ages (see Fig. 8). It shows that in the young plume, which is normally near the city area, $\mathrm{O}_{3}$ concentrations are not very sensitive to $\mathrm{NO}_{\mathrm{x}}$ concentrations. The ratio of $\Delta\left[\mathrm{O}_{3}\right] / \Delta\left[\mathrm{NO}_{\mathrm{x}}\right]$ (the slope of the fits shown in Fig. 8) is only about 4.7. By contrast, $\mathrm{O}_{3}$ concentrations are very sensitive to $\mathrm{NO}_{\mathrm{x}}$ concentrations in the aged plume. The ratio of $\Delta\left[\mathrm{O}_{3}\right] / \Delta\left[\mathrm{NO}_{\mathrm{x}}\right]$ rapidly increases to 30 in the aged plume, indicating that the slope of $\Delta\left[\mathrm{O}_{3}\right] / \Delta\left[\mathrm{NO}_{\mathrm{x}}\right]$ is about 7 times higher in the aged plume than in the young plume. The calculated slope of $\Delta\left[\mathrm{O}_{3}\right] / \Delta\left[\mathrm{NO}_{\mathrm{x}}\right]$ is consistent with the measured result. Because the aircraft measurements did not generally follow the city plumes, the measured results can be considered as the values of $\mathrm{NO}_{\mathrm{x}}$ and $\mathrm{O}_{3}$ measured in different locations (Euclidian domain). The $\mathrm{O}_{3}-\mathrm{NO}_{\mathrm{x}}$ relationship in different chemical age regimes can also be applied for different spatial locations (such as nearby cities, remote areas). The analysis of $\mathrm{O}_{3}-\mathrm{NO}_{\mathrm{x}}$ relationship in this study suggests that the slope of $\Delta\left[\mathrm{O}_{3}\right] / \Delta\left[\mathrm{NO}_{\mathrm{x}}\right]$ is lower in the areas nearby city than in the remote areas.

\section{3 $\mathrm{O}_{3}$ and $\mathrm{CO}$ relationship}

Parrish et al. (1998) studied $\mathrm{O}_{3}-\mathrm{CO}$ correlations and found that there were different slopes of $\Delta\left[\mathrm{O}_{3}\right] / \Delta[\mathrm{CO}]$ under different conditions (locations), with a larger $\mathrm{O}_{3}-\mathrm{CO}$ slope implying a higher $\mathrm{O}_{3}$ production efficiency. In this study, the $\mathrm{O}_{3}-\mathrm{CO}$ correlation is shown in Fig. 9. The data in this study 


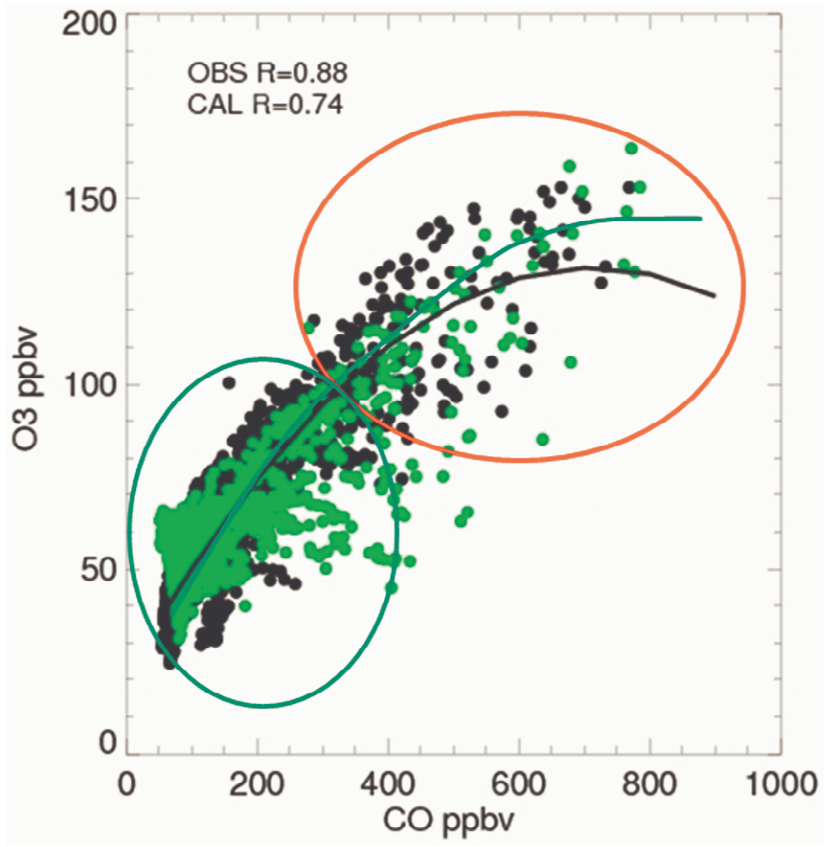

Fig. 9. Measured (black dots and line) and calculated (green dots and line) $\mathrm{O}_{3}-\mathrm{CO}$ correlation. The red circle represent the flights are roughly in the city plume regime, and green circle represents the flights are roughly in the background regime. The lines used the second-order polynomial fits for measured and modeled results.

are somewhat different than the previous studies. For example, Parrish et al. (1998) studied the $\mathrm{O}_{3}-\mathrm{CO}$ correlation for 5 surface sites. By contrast, the data used in this study are collected from aircraft which covered a larger spatial domain, including different chemical conditions (city plumes, backgrounds, young, and aged cases). In other words, the $\mathrm{O}_{3}-\mathrm{CO}$ correlation in this study can be considered a combined result from multiple local sites. The result of this study suggests that the $\mathrm{O}_{3}-\mathrm{CO}$ correlation is non-linear. When the concentrations of $\mathrm{CO}$ are less than $400 \mathrm{ppbv}$, the measured slope of $\Delta\left[\mathrm{O}_{3}\right] / \Delta[\mathrm{CO}]$ is large, with a value of 0.175 . While the concentrations of $\mathrm{CO}$ are greater than $400 \mathrm{ppbv}$, the measured slope is reduced to 0.05 . As we described before, the data used to calculate $\mathrm{O}_{3}$-CO correlation covers different aged plumes (as shown in Fig. 1). If we assume that the high $\mathrm{CO}$ concentration conditions represent young city air and low concentrations aged background conditions, the high $\mathrm{O}_{3}-\mathrm{CO}$ suggests that additional $\mathrm{O}_{3}$ is produced in the aged plume. Otherwise, the slope of $\mathrm{O}_{3}-\mathrm{CO}$ correlation should be the same in different ages of plumes. This result is consistent with the study by Wood et al. (2008) who found that the ratio $\Delta\left[\mathrm{O}_{3}\right] / \Delta[\mathrm{CO}]$ increases with the age of plumes, suggesting that secondary VOCs are more efficient at producing $\mathrm{O}_{3}$ in aged plumes. The WRF-Chem calculated ratio of $\Delta\left[\mathrm{O}_{3}\right] / \Delta[\mathrm{CO}]$ is consistent with the measured result. However, the $\Delta\left[\mathrm{O}_{3}\right] / \Delta[\mathrm{CO}]$ slope in the young plume is overestimated. In the aged plume, the calculated slope is very

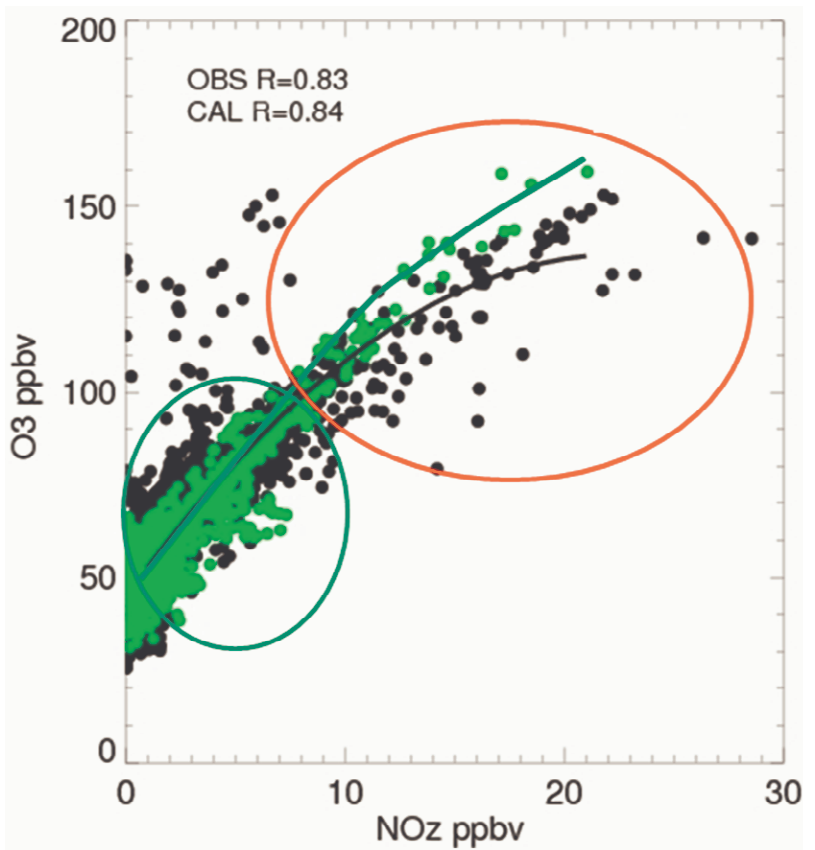

Fig. 10. Same as Fig. 9 except for $\mathrm{O}_{3}-\mathrm{NO}_{\mathrm{Z}}$ correlation.

similar to the measured value. Because of this non-linear relationship, the correlation coefficient between $\mathrm{O}_{3}$ and $\mathrm{CO}$ is reduced, with values of 0.88 and 0.74 for measurement and calculation, respectively.

\section{$4.4 \mathrm{O}_{3}$ and $\mathrm{NO}_{z}$ relationship}

$\mathrm{NO}_{\mathrm{z}}$ is the product of $\mathrm{NO}_{\mathrm{x}}$ oxidation, and the rate of oxidation of $\mathrm{NO}_{\mathrm{x}}$ to $\mathrm{NO}_{\mathrm{z}}$ is a main factor to determine $\mathrm{O}_{3}$ production efficiency which is defined by number of ozone molecules produced per molecule of nitrogen oxides consumed (Liu et al., 1987). Because $\mathrm{O}_{3}$ production is also correlated to $\mathrm{NO}_{\mathrm{z}}$ in a non-linear way (Godowitch et al., 2008; Fischer et al., 2003), the slope of $\Delta\left[\mathrm{O}_{3}\right] / \Delta\left[\mathrm{NO}_{\mathrm{z}}\right]$ provides useful information for the $\mathrm{O}_{3}$ production efficiency in different chemical conditions. Figure 10 shows the calculated and measured $\mathrm{O}_{3}-\mathrm{NO}_{7}$ correlations. It shows that when $\mathrm{NO}_{z}$ concentrations are high nearby the city area (young city plume) $\mathrm{O}_{3}$ concentrations are not very sensitive to $\mathrm{NO}_{z}$ concentrations. The ratio of $\Delta\left[\mathrm{O}_{3}\right] / \Delta\left[\mathrm{NO}_{\mathrm{z}}\right]$ is about 3.3. The ratio increases to 5.7 in the low $\mathrm{NO}_{\mathrm{z}}$ regime (in the aged plume). According to the study by Zanis et al. (2007), the large $\Delta\left[\mathrm{O}_{3}\right] / \Delta\left[\mathrm{NO}_{\mathrm{z}}\right]$ slope indicates high ozone production efficiency, a result consistent with what we found here. $s$ The WRF-Chem calculation shows a similar result to the measurement in the aged plumes. However, the calculated ratio of $\Delta\left[\mathrm{O}_{3}\right] / \Delta\left[\mathrm{NO}_{\mathrm{Z}}\right]$ is generally overestimated in the young plumes. Recent studies by Shon et al. (2008) and MenaCarrasco et al. (2009) also suggest that the ozone production efficiency is higher in remote regions than in urban areas. 

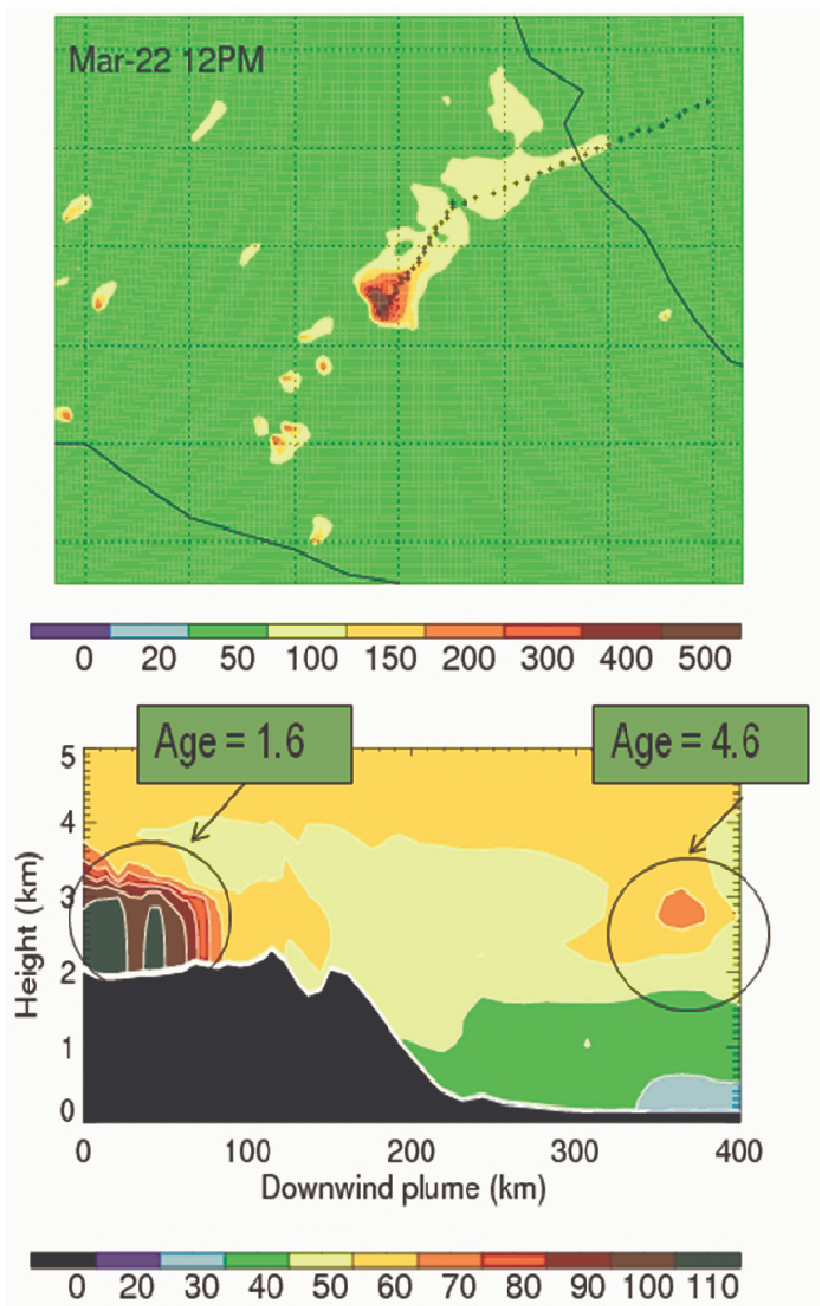

Fig. 11. Calculated plume track for the flight of 22 March (upper panel). The contour lines are the calculated CO column concentrations from the surface to $2 \mathrm{~km}$ at 12:00 p.m., and the cross dots represent the downwind plume track. The lower panel shows the $\mathrm{O}_{3}$ (ppbv) cross-section of the plume following the downwind plume track, with two $\mathrm{O}_{3}$ maxima shown for different chemical ages.

\subsection{The roles of different precursors for $\mathrm{O}_{3}$ production in the plume}

In order to study the causes of the different slopes of $\mathrm{NO}_{\mathrm{x}}$ $\mathrm{O}_{3}, \mathrm{CO}-\mathrm{O}_{3}$, and $\mathrm{NO}_{\mathrm{z}}-\mathrm{O}_{3}$ in different aged plumes, the WRFChem model was extensively applied to study the roles of ozone precursors on ozone production along the city plumes. The model has several advantages in analyzing ozone production in different aged plumes. First, tracing plumes in the model can be considered as a Lagrangian way for studying chemistries coupled with dilution in plumes. Second, the individual effect of $\mathrm{O}_{3}$ precursors on $\mathrm{O}_{3}$ formation can be separately studied in the model.

The methodology used here is to track the city plume by following the high $\mathrm{CO}$ column concentrations from the city to downwind regions. For example, the column $\mathrm{CO}$ in the flight of 22 March is shown in Fig. 11. From Fig. 11, we see that the outflow of the city plume is predominantly toward the northeast. The cross section (altitude vs. downwind distance) of $\mathrm{O}_{3}$ concentrations in the plume (lower panel of Fig. 11) suggests that the pollutants are not limited to the PBL with plumes reaching about 3-4 km above the surface (the calculated PBL height in the model ranges 1.5 to $2 \mathrm{~km}$ on this day). The calculated $\mathrm{O}_{3}$ concentrations in the plume show that there is a maximum concentration near the city (plume age near 1.6) with concentrations of more than 100 ppbv. There is also a secondary $\mathrm{O}_{3}$ maximum at 300$400 \mathrm{~km}$ downwind of the city. At this location, the $\mathrm{O}_{3}$ concentrations have another maximum of $75 \mathrm{ppbv}$ (the plume age is about 4.6). In order to understand the secondary $\mathrm{O}_{3}$ maximum, the air mass from the city was tracked from 21 March (first-day) to 22 March (second-day). During the two day period, the prevailing wind shifted from northward wind (21 March) to northeastward wind (22 March). As a result, the first-day $\mathrm{CO}$ maximum was transported northwardly to $100-200 \mathrm{~km}$ downwind during evening of 21 March. During the second day, there was a second-day $\mathrm{CO}$ maximum in the city area, while the first-day $\mathrm{CO}$ maximum was transported northeastwardly to $200-300 \mathrm{~km}$ downwind during the morning of 22 March. The first-day CO maximum was future transported northeastwardly to $300-400 \mathrm{~km}$ downwind of the city.

In order to estimate the causes for the ozone maximum in the aged plume, the reactivity of $\mathrm{OH}$ with various compounds $X$, i.e. $k_{\mathrm{OH}+X}[X]$ is calculated. These chemical compounds include $\mathrm{CO}$, slow reactive VOCs (alkanes), very reactive VOCs (alkenes and aromatic), and OVOCs (oxygenated VOCs including cresol, formaldehyde, ketones, glyoxal, methyl glyoxal, unsaturated dicarbonyl, peroxyacetyl nitrate, and organic nitrate). Figure 12 shows the reactivity of $\mathrm{OH}$ with these 4 types of compounds. The result shows that: (1) the $\mathrm{CO}$ reactivity is significant both in the city area and in the aged plume, but its relative importance in the urban area is less than the other types of reduced compounds. This is because although the $\mathrm{OH}$ reaction with $\mathrm{CO}$ is a major chemical destruction for $\mathrm{CO}$, and the rate constant is relatively small. As a result, large amounts of $\mathrm{CO}$ are transported from the city to the downwind area. For example, the CO concentration is about $300 \mathrm{ppbv}$ at $300 \mathrm{~km}$ along the plume (not shown), and the high CO concentrations in the aged plume result in the high $\mathrm{OH}$ reactivity in the aged plume. (2) The rate constants for $\mathrm{OH}+$ alkenes and $\mathrm{OH}+$ aromatics are about 20-100 times higher than the rate constant for $\mathrm{OH}+\mathrm{CO}$. The fast rate constants lead to high $\mathrm{OH}$ reactivity in the city area, making these precursors the major ones for ozone production within Mexico City (Madronich, 2006; Tie et al., 2007). As a result, a large portion of alkenes+aromatics is chemically destroyed near the city, and thus less is transported downwind leading to the small $\mathrm{OH}$ reactivity in the aged plume. (3) OVOCs are mainly produced by chemical reactions in the 

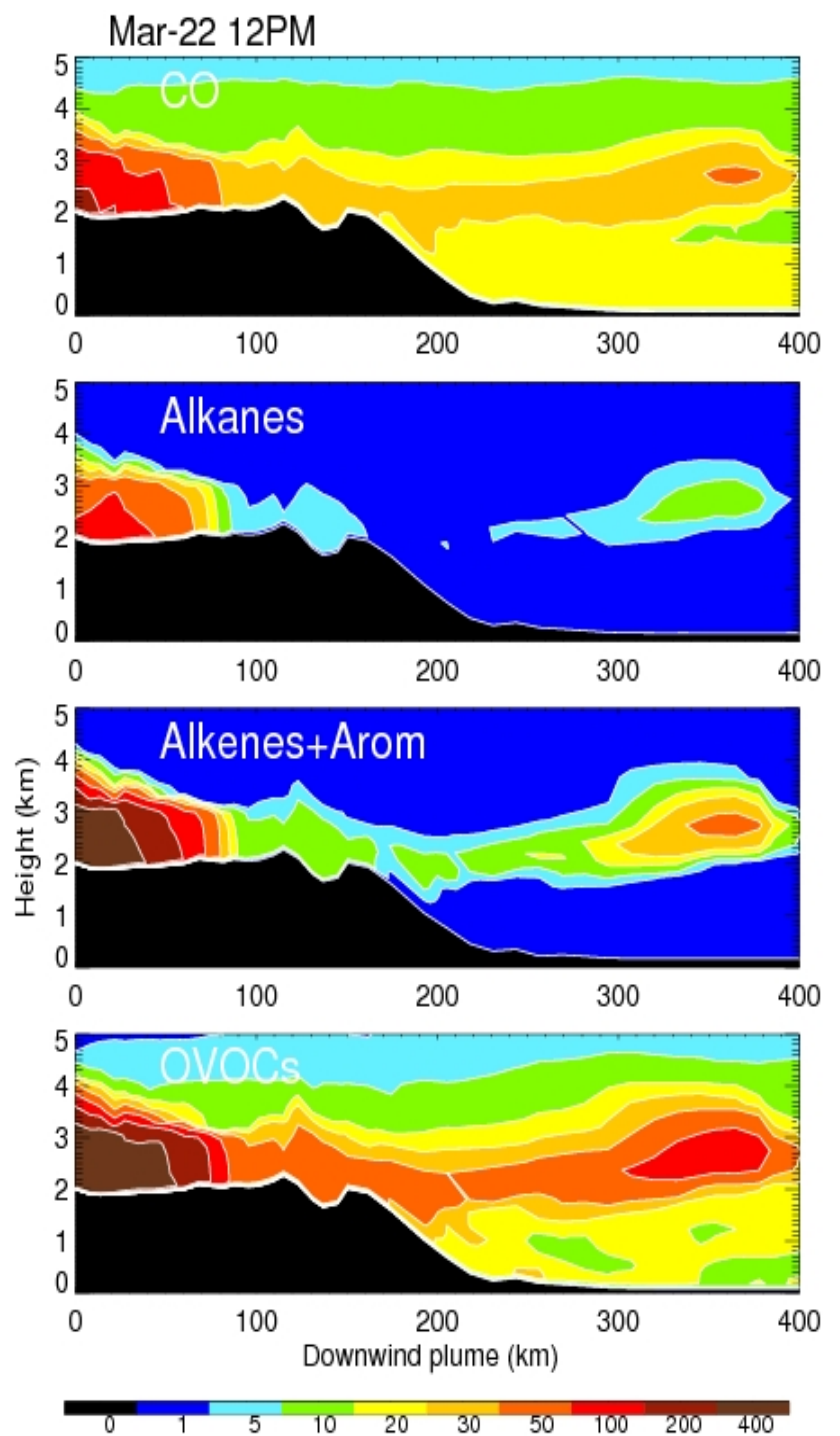

Fig. 12. Calculated $\mathrm{OH}$ reactivities $\left(\right.$ minutes $^{-1}$ ) for $\mathrm{CO}$, alkanes, alkenes+aromatic, and oxygenated VOCs (including cresol, formaldehyde, ketones, glyoxal, methyl glyoxal, unsaturated dicarbonyl, peroxyacetyl nitrate, and organic nitrate) at noontime for the flight 22 of March.

outflow, including the reactions of $\mathrm{OH}$ with alkenes, aromatics, etc. and make important contributions to the $\mathrm{OH}$ reactivity near the city as well as in the aged plume. (4) The rate of alkane reactions with $\mathrm{OH}$ is relatively low compared to alkenes or aromatics. In the Mexico City area, the alkane concentrations are lower than CO (Velasco et al., 2007; Tie et al., 2007), although the rate of reaction with $\mathrm{OH}$ is higher than $\mathrm{CO}$. As a result, alkanes contribute to $\mathrm{OH}$ reactivity in both young and aged plumes, but are usually not the dominant species in either.

\subsection{The $\mathrm{O}_{3}$ production efficiency in the plume}

The oxidization of CO and VOCs leads to the production of $\mathrm{HO}_{2}$ and $\mathrm{RO}_{2}$ radicals. Thus $\mathrm{O}_{3}$ is produced in the presence of NO by following reactions:

$$
\begin{aligned}
& \mathrm{HO}_{2}+\mathrm{NO} \rightarrow \mathrm{NO}_{2}+\mathrm{OH} \\
& \mathrm{RO}_{2}+\mathrm{NO} \rightarrow \mathrm{NO}_{2}+\mathrm{RO} \\
& \mathrm{NO}_{2}+h v \rightarrow \mathrm{NO}+\mathrm{O} \\
& \mathrm{O}+\mathrm{O}_{2} \rightarrow \mathrm{O}_{3}
\end{aligned}
$$

As a result, $\mathrm{O}_{3}$ is produced through the Reaction (R1) through (R4) reactions and the rate-determining steps are Reactions (R1) and (R2). The NO is re-generated in Reaction ( $\mathrm{R} 3$ ), so that it can participate in this $\mathrm{O}_{3}$-producing cycle more than once. At high $\mathrm{NO}_{\mathrm{x}}$, the main termination of this cycle is the reaction

$\mathrm{NO}_{2}+\mathrm{OH} \rightarrow \mathrm{HNO}_{3}$

The $\mathrm{O}_{3}$ production efficiency $(S)$ was defined by Liu et al. (1987) as

$S=P\left(\mathrm{O}_{3}\right) / L\left(\mathrm{NO}_{\mathrm{X}}\right)$

where $P\left(\mathrm{O}_{3}\right)$ and $L\left(\mathrm{NO}_{\mathrm{x}}\right)$ are the production of $\mathrm{O}_{3}$ and the loss of $\mathrm{NO}_{\mathrm{x}}$, respectively. According to the studies by Liu et al. (1987) and Lin et al. (1988), the advantage of using the $\mathrm{O}_{3}$ production efficiency is that the variations in $\mathrm{O}_{3}$ production and $\mathrm{NO}_{\mathrm{x}}$ loss are often similar and therefore cancel each other. The $\mathrm{O}_{3}$ production efficiency $(S)$ is the ratio between $\mathrm{O}_{3}$ production and $\mathrm{NO}_{\mathrm{x}}$ loss, which reduces substantially the uncertainty in the estimated total regional $\mathrm{O}_{3}$ production. However, significant nonlinearity still exists (Liu et al., 1987). Lin et al. (1988) used both absolute $\mathrm{O}_{3}$ production and net $\mathrm{O}_{3}$ production (including $\mathrm{O}_{3}$ chemical production and the effect of transport) for the calculation of the $\mathrm{O}_{3}$ production efficiency, and found that the $\mathrm{O}_{3}$ production efficiency is about 20-30\% (??) by using absolute $\mathrm{O}_{3}$ production than net $\mathrm{O}_{3}$ production. In this study, we use the absolute $\mathrm{O}_{3}$ production calculated from the Reactions (R1) and (R2) to study the $\mathrm{O}_{3}$ production efficiency along the city plume, which is expressed by

$$
\begin{aligned}
& S=\left(P\left[\mathrm{HO}_{2}\right]+P\left[\mathrm{RO}_{2}\right]\right) /\left(k_{9} \times\left[\mathrm{NO}_{2}\right][\mathrm{OH}]\right) \\
& P\left[\mathrm{HO}_{2}\right]=\left(k_{5} \times\left[\mathrm{HO}_{2}\right][\mathrm{NO}]\right) \\
& P\left[\mathrm{RO}_{2}\right]=\left(\Sigma k_{6 i} \times\left[\mathrm{RO}_{2}\right]_{i}[\mathrm{NO}]\right)
\end{aligned}
$$

Where $P\left[\mathrm{HO}_{2}\right]$ and $P\left[\mathrm{RO}_{2}\right]$ represent the $\mathrm{O}_{3}$ production due to the oxidation of $\mathrm{NO}$ with $\mathrm{HO}_{2}$ and $\mathrm{RO}_{2}$, respectively. Note that there are several types of $\mathrm{RO}_{2}$, and thus $\left[\mathrm{RO}_{2}\right]_{i}$ represents different $\mathrm{RO}_{2}$ species, which are mainly produced by the oxidation of VOCs by $\mathrm{OH}$. The parameters of $k_{5}, k_{6 i}$, 
and $k_{9}$ are the rate coefficients for Reactions (R1), (R2), and (R5), respectively.

The calculated $\mathrm{O}_{3}$ production efficiency $(S)$ along the city plume is shown in Fig. 13a (upper panel). The $\mathrm{O}_{3}$ production efficiency is higher in the aged plume with a maximum value of 60-80 and is lower near the city with a minimum value of 10 , suggesting that the $\mathrm{O}_{3}$ production is about 6 times more efficient in the aged plume than in the young plume. This result explains that the secondary $\mathrm{O}_{3}$ maximum in the aged plume shown in Fig. 11 arises from the facts that: (1) there are high $\mathrm{OH}$ reactivities, largely due to the OVOCs oxidation, leading to the production of large amount $\mathrm{RO}_{2}$. (2) The $\mathrm{O}_{3}$ production efficiency is much higher in the aged plume than in the young plume, leading to more production of $\mathrm{O}_{3}$ molecules with each $\mathrm{NO}_{\mathrm{x}}$ molecular being consumed in the aged plume. As a result, even though the $\mathrm{NO}_{\mathrm{x}}$ concentrations are low, a fairly large amount of $\mathrm{O}_{3}$ is produced in the aged plumes. The high $\mathrm{O}_{3}$ production efficiency is associated with lower concentrations of $\mathrm{NO}_{\mathrm{x}}$. As a result, the high $\mathrm{O}_{3}$ production efficiency cannot be considered as high $\mathrm{O}_{3}$ production rate. For example, the lower panel of Fig. 13a shows that although the production efficiency is lower in the city, the rate of $\mathrm{O}_{3}$ production is highest ( $30 \mathrm{ppbv} /$ hour). By contrast, the rate of $\mathrm{O}_{3}$ production is low in the aged plume ( $0.3 \mathrm{ppbv} /$ hour), although the production efficiency is highest in this region.

From Eq. (4), there are 2 important components in contributing to the $\mathrm{O}_{3}$ production and production efficiency. One is through the $\mathrm{HO}_{2}+\mathrm{NO}$ reaction $\left(P\left[\mathrm{HO}_{2}\right]\right)$, and another is through the $\mathrm{RO}_{2}+\mathrm{NO}$ reaction $\left(P\left[\mathrm{RO}_{2}\right]\right)$. Because $\mathrm{HO}_{2}$ and $\mathrm{RO}_{2}$ result from different oxidation processes (e.g., $\mathrm{CO}$ oxidation produces only $\mathrm{HO}_{2}$ radicals, while VOC oxidation produce both $\mathrm{HO}_{2}$ and $\mathrm{RO}_{2}$ radicals), it is important to understand the individual contributions of $\mathrm{HO}_{2}$ and $\mathrm{RO}_{2}$ to the $\mathrm{O}_{3}$ production and production efficiency.

Figure 13b shows the individual contribution of $\mathrm{P}\left[\mathrm{HO}_{2}\right]$ and $\mathrm{P}\left[\mathrm{RO}_{2}\right]$ for the $\mathrm{O}_{3}$ production and production efficiency.

$$
\begin{aligned}
& S_{\mathrm{HO}_{2}}=P\left[\mathrm{HO}_{2}\right] /\left(k_{9} \times\left[\mathrm{NO}_{2}\right][\mathrm{OH}]\right) \\
& S_{\mathrm{RO}_{2}}=P\left[\mathrm{RO}_{2}\right] /\left(k_{9} \times\left[\mathrm{NO}_{2}\right][\mathrm{OH}]\right)
\end{aligned}
$$

The result shows that both the $S_{\mathrm{HO}_{2}}$ and $S_{\mathrm{RO}_{2}}$ are lower nearby the city (young plume) than the aged plume. For example, values of $S_{\mathrm{HO}_{2}}$ and $S_{\mathrm{RO}_{2}}$ are about 10 and 5 in the young plume and 20 to 50 in the aged plume, respectively. However, there is an important difference between the values of $S_{\mathrm{HO}_{2}}$ and $S_{\mathrm{RO}_{2}}$. The high values of $S_{\mathrm{RO}_{2}}$ are mostly located in the aged plume (as shown in lower panel). By contrast, the high values of $\mathrm{S}_{\mathrm{HO}_{2}}$ are distributed throughout the entire plume. The wide distribution of $\mathrm{S}_{\mathrm{HO}_{2}}$ can be explained by the fact that $\mathrm{CO}$ concentrations are widely distributed because of its long chemical lifetime. As a result, the $\mathrm{HO}_{2}$ concentrations are more uniformly distributed, while the large $\mathrm{RO}_{2}$ concentrations are mostly found in the plume. This result suggests that the high $\mathrm{O}_{3}$ production efficiency in the
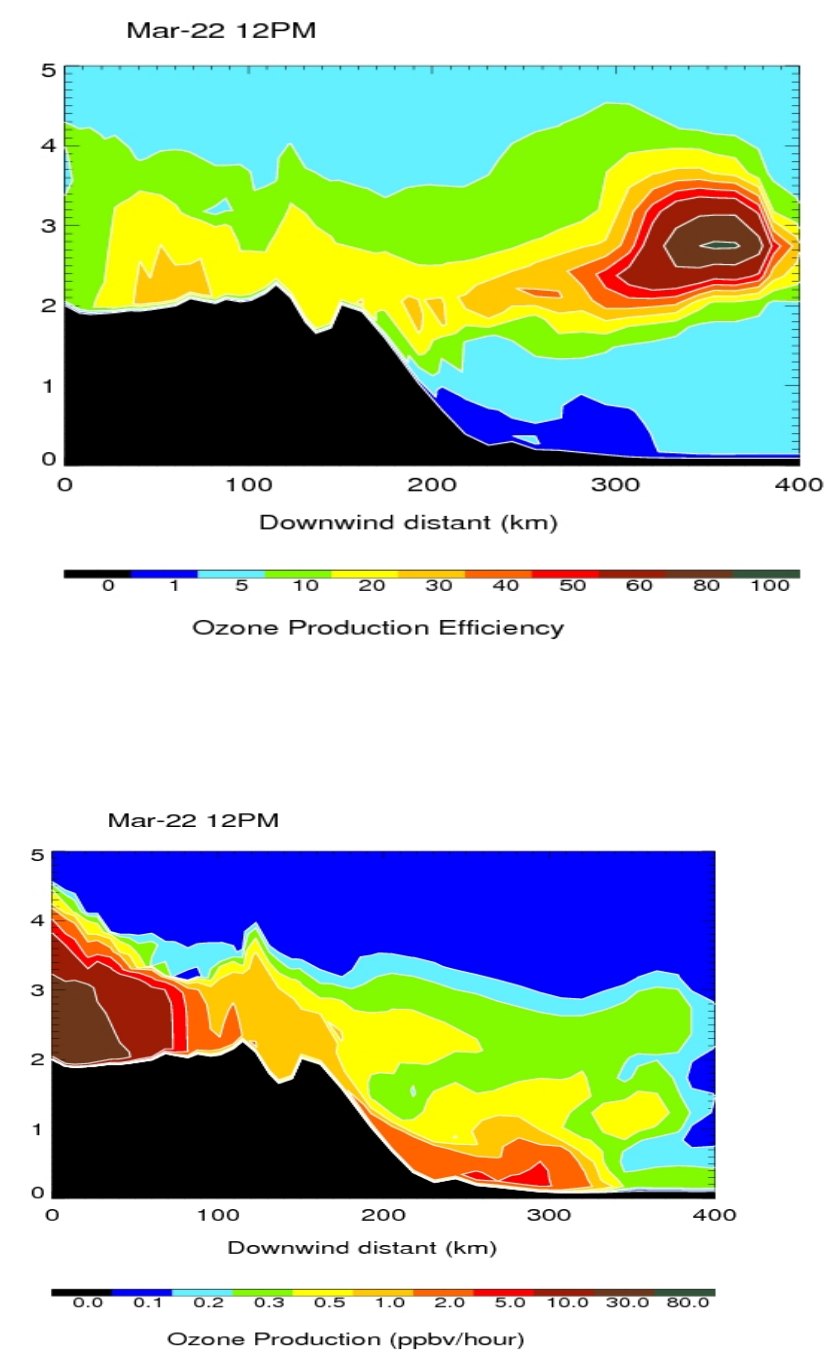

Fig. 13a. Calculated $\mathrm{O}_{3}$ production efficiency (upper panel) and the rate of $\mathrm{O}_{3}$ production (ppbv/hour) along the plume track at noontime for the flight of 22 March.

aged plume (showing in Fig. 13a) is largely results from the $\mathrm{RO}_{2}+\mathrm{NO}$ reactions and a small portion from the $\mathrm{HO}_{2}+\mathrm{NO}$ reaction. Figure $13 \mathrm{c}$ shows the noontime concentrations of $\mathrm{OH}, \mathrm{HO}_{2}$, and $\mathrm{RO}_{2}$ along the city plume. The results indicate that $\mathrm{OH}$ concentrations are lower inside the plume; $\mathrm{HO}_{2}$ concentrations are more uniformly distributed; and $\mathrm{RO}_{2}$ concentrations are enhanced inside the plume. This result suggests that the air pollutants emitted from the city intend to convert $\mathrm{OH}$ to $\mathrm{RO}_{2}$ inside the plume. There is also a clear indication that the largest enhancement of $\mathrm{RO}_{2}$ occurs at aged plume region, which results in highest $\mathrm{O}_{3}$ production efficiency in this region (see the lower panel of Fig. 13b). 


\section{Mar-22 12PM}
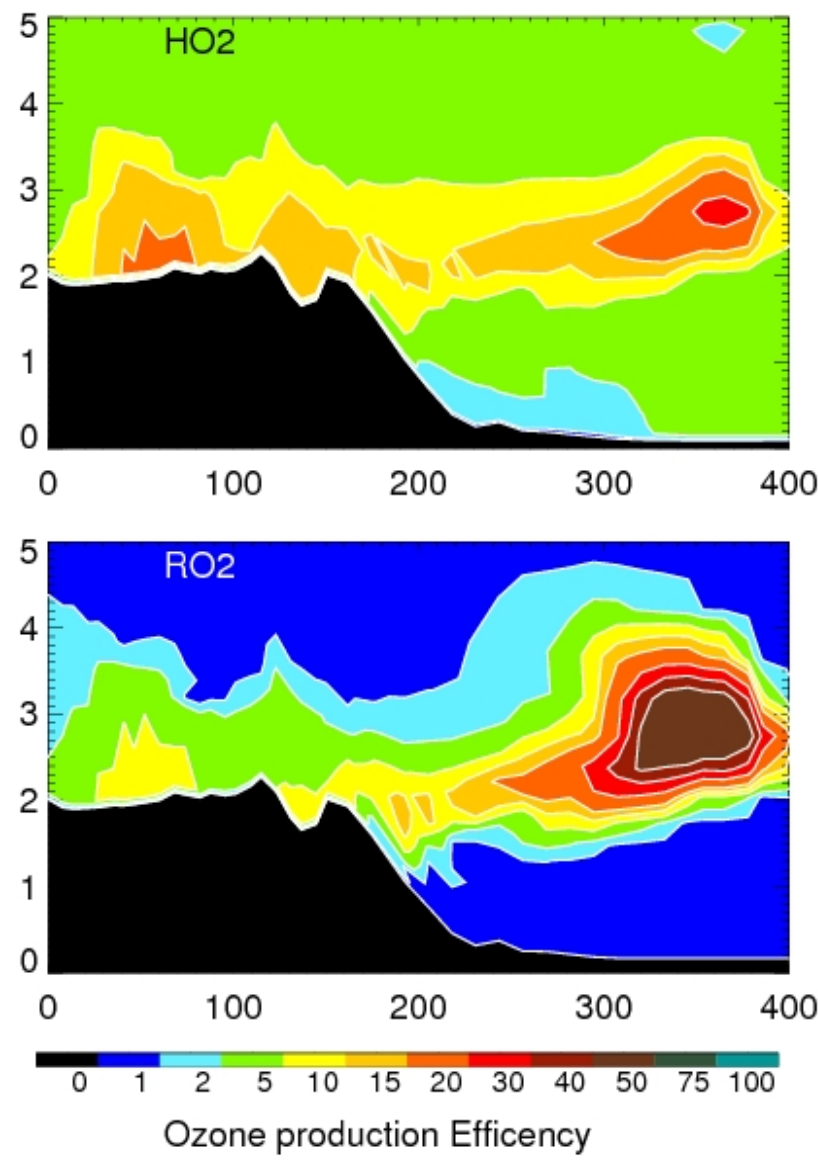

Fig. 13b. Calculated $\mathrm{O}_{3}$ production efficiency from $\mathrm{HO}_{2}$ and $\mathrm{RO}_{2}$ contributions, respectively.

\section{Summary}

The $\mathrm{O}_{3}$ concentration and its evolution in the Mexico City plume during the MIRAGE-Mex field campaign were studied. The in-situ aircraft measurements of $\mathrm{O}_{3}, \mathrm{CO}$, VOCs, $\mathrm{NO}_{\mathrm{x}}$, and $\mathrm{NO}_{\mathrm{y}}$ concentrations were compared to the calculations of a regional chemical/transport model (WRF-Chem). The model calculation was also used to interpret the measured results, and to understand the $\mathrm{O}_{3}$ evolution in the downwind of the Mexico City plume. The comparisons between the calculations and measurements can be summarized by the following aspects: (1) the WRF-Chem model has a capability to capture the measured city plumes, and the calculated variability along the flight routes is generally consistent with the measured results, showing a rapid enhancement when city plumes are detected. (2) From the evaluation of $\mathrm{CO}$ concentrations (considered as a chemically inactive tracer) in both the surface measurements and the aircraft measurements, the transport from the surface of the city to the plume levels (ranging from 3 to $5 \mathrm{~km}$ ) is underestimated
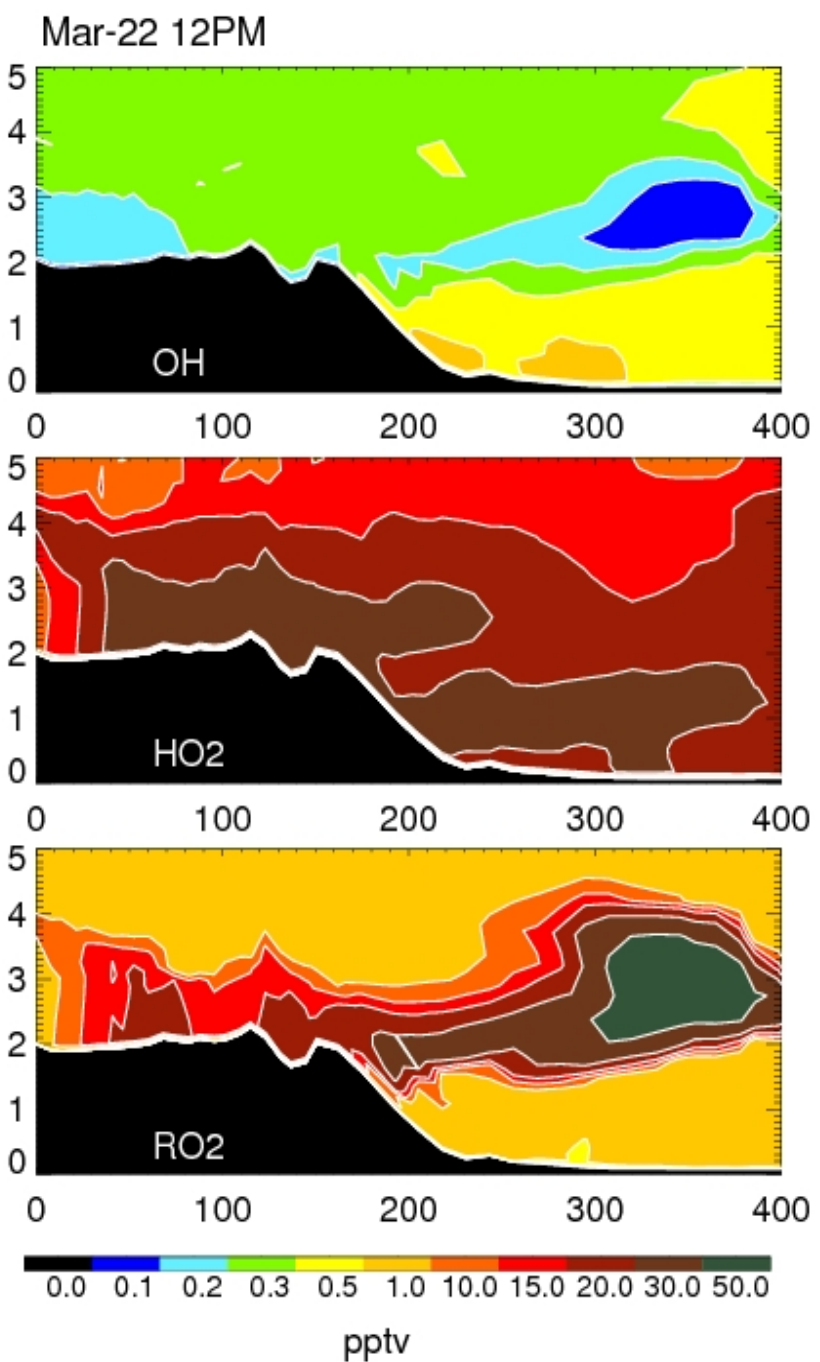

Fig. 13c. Calculated $\mathrm{OH}, \mathrm{HO}_{2}, \mathrm{RO}_{2}$ concentrations (pptv) along the plume track at noontime for the flight of 22 March.

by about 0 to $25 \%$ during 5 different flights. This contributes to the underestimation of some long-lived chemical species $\left(\mathrm{CO}, \mathrm{O}_{3}, \mathrm{NO}_{\mathrm{y}}\right.$, etc.) in the plumes. (3) The uncertainties in calculating $\mathrm{CO}, \mathrm{O}_{3}, \mathrm{NO}_{\mathrm{x}}$, VOC concentrations in the city plumes are -50 to $+20 \%$. After adjustment for the transport processes based on $\mathrm{CO}$ concentrations and background concentrations, the uncertainty range is reduced to about -20 to $+20 \%$ which is probably mostly related to the surface emission estimates, and other uncertain processes.

The results show that $\mathrm{OH}$ reactivity with $\mathrm{CO}$ is relatively low in the city area (the young plume), but increases relatively in the aged plume. This is because the $\mathrm{OH}$ reaction with $\mathrm{CO}$ is a major chemical destruction mechanism for $\mathrm{CO}$, and the rate of reaction is low. As a result, large amounts of $\mathrm{CO}$ are transported from the city to the downwind area, resulting in ongoing $\mathrm{OH}$ reactivity. Alkene and aromatic reaction rates with $\mathrm{OH}$ are high. As a result, the fast reactions 
lead to high $\mathrm{OH}$ reactivity in the city area, and low $\mathrm{OH}$ reactivity in the aged plume. OVOCs are mainly chemically produced by chemical reactions. Thus, OVOCs are continuously produced along the city plume, and have important contributions to the $\mathrm{OH}$ reactivity near the city as well as in the aged plume. Alkanes contribute to the $\mathrm{OH}$ reactivity in both young and old plumes, but usually are not the dominant species in either. The analysis of measurements $\left(\mathrm{O}_{3}-\right.$ $\mathrm{CO}, \mathrm{O}_{3}-\mathrm{NO}_{\mathrm{x}}$, and $\mathrm{O}_{3}-\mathrm{NO}_{\mathrm{z}}$ correlations) and the calculation of the $\mathrm{O}_{3}$ production efficiency $(S)$ showed that the ozone production was more efficient in the aged plume than in the young plume, indicating that substantial $\mathrm{O}_{3}$ production occur downwind of the city, adding to the $\mathrm{O}_{3}$ already produced in the city and exported with the plume.

Acknowledgements. The authors would like to thank George Grell and Steve Peckham at NOAA for providing us with the WRF-Chem model. We wish to thank Geoff Tyndall and Alan Fried for helpful discussions. The National Center for Atmospheric Research is sponsored by the National Science Foundation

Edited by: J. Gaffney

\section{References}

Apel, E. C., Brauers, T., Koppmann, R., et al.: Intercomparison of oxygenated volatile organic compound measurements at the SAPHIR atmosphere simulation chamber, J. Geophys. Res., 113, D20307, doi:10.1029/2008JD009865, 2008.

Brasseur, G., Orlando, J., and Tyndall, G.: Atmospheric Chemistry and Global Change, Oxford University Press, 1999.

Crutzen, P. J.: Physical and chemical processes which control the production, destruction, and distribution of ozone and some other chemically active minor constituents, GARP Publications Series, 16, 236-243. 1975.

Chameides, W. L. and Walker, J.: Time dependent photochemical model for ozone near the ground, J. Geophys. Res., 81, 413-420. 1976.

Chang, J. S., Binkowski, F. S., Seaman, N. L., McHenry, J. N., Samson, P. J., Stockwell, W. R., Walcek, C. J., Madronich, S., Middleton, P. B., Pleim, J. E., and Lansford, H. H.: The regional acid deposition model and engineering model, State-ofScience/Technology, Report 4, National Acid Precipitation Assessment Program, Washington DC, 1989.

de Foy, B., Varela, J. R., Molina, L. T., and Molina, M. J.: Rapid ventilation of the Mexico City basin and regional fate of the urban plume, Atmos. Chem. Phys., 6, 2321-2335, 2006, http://www.atmos-chem-phys.net/6/2321/2006/.

Fast, J. D., de Foy, B., Acevedo Rosas, F., Caetano, E., Carmichael, G., Emmons, L., McKenna, D., Mena, M., Skamarock, W., Tie, X., Coulter, R. L., Barnard, J. C., Wiedinmyer, C., and Madronich, S.: A meteorological overview of the MILAGRO field campaigns, Atmos. Chem. Phys., 7, 2233-2257, 2007, http://www.atmos-chem-phys.net/7/2233/2007/.

Fischer, H., Kormann, R., Klüpfel, T., Gurk, Ch., Königstedt, R., Parchatka, U., Mühle, J., Rhee, T. S., Brenninkmeijer, C. A. M., Bonasoni, P., and Stohl, A.: Ozone production and trace gas correlations during the June 2000 MINATROC intensive measure- ment campaign at Mt. Cimone, Atmos. Chem. Phys., 3, 725-738, 2003, http://www.atmos-chem-phys.net/3/725/2003/.

Godowitch J. M., Hogrefe, C., and Rao, S. T.: Diagnostic analyses of a regional air quality model: Changes in modeled processes affecting ozone and chemical-transport indicators from $\mathrm{NO}_{\mathrm{x}}$ point source emission reductions, J. Geophys. Res., 113, D19303, doi:10.1029/2007JD009537, 2008.

Grell, G. A., Peckham, S. E., Schmitz, R., McKeen, S. A., Wilczak, J., and Eder, B.: Fully coupled "online" chemistry within the WRF model, Atmos. Environ., 39, 6957-6975, 2005.

Hong, S., Noh, Y., and Dudhia, J. A.: New Vertical Diffusion Package with an Explicit Treatment of Entrainment Processes, Mon Weather Rev., 134, 2318-2341, 2006.

Horowitz, L. W., Walters, S., Mauzerall, D. L., Emmons, L. K., Rasch, P. J., Granier, C., Tie, X. X., Lamarque, J. F., Schultz, M G., Tyndall, G. S., Orlando, J. J., and Brasseur, G. P.: A global simulation of tropospheric ozone and related tracers: Description and evaluation of MOZART, version 2, J. Geophys. Res., 108, 4784, doi:10.1029/2002JD002853, 2003.

Kleinman, L. I., Daum, P. H., Imre, D. G., Lee, J. H., Lee, Y.-N., Nunnermacker, L. J., Springston, S. R., WeinsteinLloyd, J., and Newman, L.: Ozone production in the New York City urban plume, J. Geophys. Res., 105, 14495-14512, doi:10.1029/2000JD900011, 2000.

Kleinman L. I., Daum, P. H., Lee, Y.-N., Nunnermacker, L. J., Springston, S. R., Weinstein-Lloyd, J., Hyde, P., Doskey, P., Rudolph, J., Fast, J., and Berkowitz, C.: Photochemical age determinations in the Phoenix metropolitan area, J. Geophys. Res., 108, 4096, doi:10.1029/2002JD002621, 2003.

Kleinman, L. I., Springston, S. R., Daum, P. H., Lee, Y.-N., Nunnermacker, L. J., Senum, G. I., Wang, J., Weinstein-Lloyd, J., Alexander, M. L., Hubbe, J., Ortega, J., Canagaratna, M. R., and Jayne, J.: The time evolution of aerosol composition over the Mexico City plateau, Atmos. Chem. Phys., 8, 1559-1575, 2008, http://www.atmos-chem-phys.net/8/1559/2008/.

Lei, W., Zavala, M., de Foy, B., Volkamer, R., and Molina, L. T.: Characterizing ozone production and response under different meteorological conditions in Mexico City, Atmos. Chem. Phys., 8, 7571-7581, 2008, http://www.atmos-chem-phys.net/8/7571/2008/.

Lin, X., Trainer, M., and Liu, S. C.: On the nonlinearity of the tropospheric ozone production, J. Geophys. Res., 93(D12), 1587915888, doi:10.1029/88JD03750, 1988.

Liu, S. C., Trainer, M., Fenhsenfeld, F. C., Parrish, D. D., Williams, H., Fahey, D. W., Hubler, G., and Murphy, D.: Ozone Production in the Rural Troposphere and the Implications, for Regional and Global Ozone Distributions, J. Geophys. Res., 92, 4191-4207, 1987.

Madronich, S. and Flocke, S.: The role of solar radiation in atmospheric chemistry, in: Handbook of Environmental Chemistry, edited by: Boule, P., Springer-Verlag, Heidelberg, 1-26, 1999.

Madronich, S.: Chemical evolution of gaseous air pollutants downwind of tropical megacities: Mexico City case study, Atmos. Environ., 40, 6012-6018, 2006.

Mena-Carrasco, M., Carmichael, G. R., Campbell, J. E., Zimmerman, D., Tang, Y., Adhikary, B., D’allura, A., Molina, L. T., Zavala, M., García, A., Flocke, F., Campos, T., Weinheimer, A. J., Shetter, R., Apel, E., Montzka, D. D., Knapp, D. J., and 
Zheng, W.: Assessing the regional impacts of Mexico City emissions on air quality and chemistry, Atmos. Chem. Phys., 9, 37313743, 2009,

http://www.atmos-chem-phys.net/9/3731/2009/.

Molina, L. and Molina, M. (Eds.): Air Quality in the Mexico MegaCity: An Integrated Assessment, Kluwer Academic Publishers, Dordrecht, 2002.

Parrish, D. D., Trainer, M., Holloway, J. S., Yee, J. E., Warshawsky, M. S., Fehsenfeld, F. C., Forbes, G. L., and Moody, J. L.: Relationships between ozone and carbon monoxide at surface sites in the North Atlantic region, J. Geophys. Res. 103, 20, 1335713376, 1998.

Ridley, B. A., Dye, J. E., Walega, J. G., Zheng, J., Grahek, F. E., and Rison, W.: On the production of active nitrogen by thunderstorms over New Mexico, J. Geophys. Res., 101(D15), 2098521006, 1996.

Shon, Z.-H., Madronich, S., Song, S.-K., Flocke, F. M., Knapp, D. J., Anderson, R. S., Shetter, R. E., Cantrell, C. A., Hall, S. R., and Tie, X.: Characteristics of the $\mathrm{NO}-\mathrm{NO}_{2}-\mathrm{O}_{3}$ system in different chemical regimes during the MIRAGE-Mex field campaign, Atmos. Chem. Phys., 8, 7153-7164, 2008, http://www.atmos-chem-phys.net/8/7153/2008/.

Singh, H. B., Kanakidou, M., Crutzen, P. J., and Jacob, D. J.: High concentrations and photochemical fate of oxygenated hydrocarbons in the global troposphere, Nature, 378, 50-54, 1995.

Sillman, S.: The use of $\mathrm{NO}_{y}, \mathrm{H}_{2} \mathrm{O}_{2}$, and $\mathrm{HNO}_{3}$ as indicators for ozone- $\mathrm{NO}_{\mathrm{x}}$-hydrocarbon sensitivity in urban locations, J. Geophys. Res., 100, 14175-14188, 1995.

Thielmann, A., Prévôt, A. S. H., and Staehelin, J.: Sensitivity of ozone production derived from field measurements in the Italian Po basin, J. Geophys. Res., 107, 8194, doi:10.1029/2000JD000119, 2002.

Tie, X., Madronich, S., Walters, S., Rasch, P., and Collins, W.: Effect of Clouds on photolysis and oxidants in the troposphere, J. Geophys. Res., 108, 4642, doi:10.1029/2003JD003659, 2003a.

Tie, X., Emmons, L., Horowitz, L., et al.: Effect of sulfate aerosol on tropospheric $\mathrm{NO}_{\mathrm{x}}$ and ozone budgets: Evidence during TOPSE, J. Geophys. Res., 108, 8364, doi:10.1029/2001JD001508, 2003b.

Tie, X., Madronich, S., Walters, S., Edwards, D. P., Ginoux, P., Mahowald, N., Zhang, R. Y., Lou, C., and Brasseur, G.: Assessment of the global impact of aerosols on tropospheric oxidants, J. Geophys. Res., 110, D03204, doi:10.1029/2004JD005359, 2005.

Tie, X., Chandra, S., Ziemke, J. R., Granier, C., and Brasseur, G.: Satellite measurements of tropospheric column $\mathrm{O}_{3}$ and $\mathrm{NO}_{2}$ in Eastern and Southeastern Asia: Comparison with a global model (MOZART-2), J. Atmos. Chem., 56, 105-125, doi:10.1007/s10874-006-9045-7, 2007.
Tie, X., Madronich, S., Li, G. H., Ying, Z. M., Zhang, R., Garcia, A., Lee-Taylor, J., and Liu, Y.: Characterizations of chemical oxidants in Mexico City: A regional chemical/dynamical model (WRF-Chem) study, Atmos. Environ., 41, 1989-2008, 2007.

Velasco, E., Lamb, B., Westberg, H., Allwine, E., Sosa, G., ArriagaColina, J. L., Jobson, B. T., Alexander, M. L., Prazeller, P., Knighton, W. B., Rogers, T. M., Grutter, M., Herndon, S. C., Kolb, C. E., Zavala, M., de Foy, B., Volkamer, R., Molina, L. T., and Molina, M. J.: Distribution, magnitudes, reactivities, ratios and diurnal patterns of volatile organic compounds in the Valley of Mexico during the MCMA 2002 \& 2003 field campaigns, Atmos. Chem. Phys., 7, 329-353, 2007, http://www.atmos-chem-phys.net/7/329/2007/.

Wesely, M. L.: Parameterization of surface resistance to gaseous dry deposition in regional-scale numerical models, Atmos. Environ., 23, 1293-1304, 1989.

West, J. J., Zavala, M. A., Molina, L. T., Molina, M. J., Martini, F. S., McRae, G. J., Iglesias, G. S., and Colina, J. L.: Modeling ozone photochemistry and evaluation of hydrocarbon emissions in the Mexico City metropolitan area, J. Geophys. Res., 109, D19312, doi:10.1029/2003JD003652, 2004.

Ying, Z. M., Tie, X., and Li, G. H.: Sensitivity of ozone concentrations to diurnal variations of surface emissions in Mexico City: A WRF/Chem modeling study, Atmos. Environ, 43, 851-859, 2009.

Zanis, P., Ganser, A., Zellweger, C., Henne, S., Steinbacher, M., and Staehelin, J.: Seasonal variability of measured ozone production efficiencies in the lower free troposphere of Central Europe, Atmos. Chem. Phys., 7, 223-236, 2007, http://www.atmos-chem-phys.net/7/223/2007/.

Zaveri, R. A., Berkowitz, C. M., Kleinman, L. I., Springston, S. R., Doskey, P. V., Lonneman, W. A., and Spicer, C. W.: Ozone production efficiency and $\mathrm{NO}_{\mathrm{x}}$ depletion in an urban plume: Interpretation of field observations and implications for evaluating $\mathrm{O}_{3}-\mathrm{NO}_{\mathrm{x}}$-VOC sensitivity, J. Geophys. Res., 108, 4436, doi:10.1029/2002JD003144, 2003.

Zhang, Y., Dubey, M. K., Olsen, S. C., Zheng, J., and Zhang, R.: Comparisons of WRF/Chem simulations in Mexico City with ground-based RAMA measurements during the 2006MILAGRO, Atmos. Chem. Phys., 9, 3777-3798, 2009, http://www.atmos-chem-phys.net/9/3777/2009/. 